\title{
Morphology of Hydatellaceae, an anomalous aQuatic FAMILY RECENTLY RECOGNIZED AS AN EARLY-DIVERGENT ANGIOSPERM LINEAGE ${ }^{1}$
}

\author{
Paula J. Rudall, ${ }^{2,8}$ Dmitry D. Sokoloff, ${ }^{3}$ Margarita V. Remizowa, ${ }^{3}$ John G. Conran, ${ }^{4}$ \\ Jerrold I. Davis, ${ }^{5}$ Terry D. Macfarlane, ${ }^{6}$ and Dennis W. Stevenson ${ }^{7}$ \\ ${ }^{2}$ Jodrell Laboratory, Royal Botanic Gardens, Kew, Richmond, Surrey TW9 3AB, UK; ${ }^{3}$ Department of Higher Plants, Biological \\ Faculty, Moscow State University, 119992, Moscow, Russia; ${ }^{4}$ CEBB, EB/EES, Benham Building, DP312, University of \\ Adelaide, Adelaide, SA 5005, Australia; ${ }^{5}$ L. H. Bailey Hortorium and Department of Plant Biology, Cornell University, Ithaca, \\ New York 14853 USA; ${ }^{6}$ CALM, c/o Manjimup Research Centre, Brain Street, 6258 Manjimup, WA, Australia; and
}

${ }^{7}$ New York Botanical Garden, Bronx, New York 10458 USA

\begin{abstract}
The family Hydatellaceae was recently reassigned to the early-divergent angiosperm order Nymphaeales rather than the monocot order Poales. This dramatic taxonomic adjustment allows comparison with other early-divergent angiosperms, both extant and extinct. Hydatellaceae possess some monocot-like features that could represent adaptations to an aquatic habit. Ecophysiological parallels can also be drawn from fossil taxa that are known from small achene-like diaspores, as in Hydatellaceae. Reproductive units of Hydatellaceae consist of perianthlike bracts enclosing several pistils and/or stamens. In species with bisexual reproductive units, a single unit resembles an "inside-out" flower, in which stamens are surrounded by carpels that are initiated centrifugally. Furthermore, involucre development in Trithuria submersa, with delayed growth of second whorl bracts, resembles similar delayed development of the second perianth whorl in Cabomba. Several hypotheses on the homologies of reproductive units in Hydatellaceae are explored. Currently, the most plausible interpretation is that each reproductive unit represents an aggregation of reduced unisexual apetalous flowers, which are thus very different from flowers of Nymphaeales. Each pistil in Hydatellaceae is morphologically and developmentally consistent with a solitary ascidiate carpel. However, ascidiate carpel development, consistent with placement in Nymphaeales, is closely similar to pseudomonomerous pistil development as in Poales.
\end{abstract}

Key words: angiosperm; flower; Hydatella; Hydatellaceae; inflorescence; ontogeny; pseudanthium; Trithuria.

"If we treat Hydatellaceae as a separate family, we adequately express their isolated and obscure systematic position and perhaps facilitate an unbiased search for their natural affinities based on more characters than hitherto known."

(Hamann, 1976, p. 194)

"The phylogenetic position of Hydatellaceae is still a riddle. It is so different from other monocotyledonous orders that its inclusion even in any superorder will be most strained."

(Dahlgren et al., 1985, p. 399)

The aquatic angiosperm family Hydatellaceae, formerly placed in the highly derived monocot order Poales, was recently reassigned to one of the most ancient extant angiosperm groups, the water-lily clade Nymphaeales, based primarily on a multigenic molecular phylogenetic analysis (Saarela et al., 2007). This dramatic taxonomic adjustment has placed Hydatellaceae close to the angiosperm stem-group, from which it is separated by a single lineage, Amborella, the putative sister to all other extant angiosperms (e.g., Soltis et al., 2000). Amborella itself is placed within Nymphaeales in some

\footnotetext{
${ }^{1}$ Manuscript received 24 November 2006; revision accepted 15 May 2007. The authors thank Thomas Stützel for kindly allowing access to the microscope slide collection of the late Prof. U. Hamann at the University of Bochum, Jeff Saarela and Sean Graham for pre-publication access to their article, and Richard Bateman, Margaret Collinson, Lina Golovneva, Favio González and Wolfgang Stuppy for discussion and comments on the manuscript. D.D.S. and M.V.R. acknowledge support from the BenthamMoxon trust and RFBR (grant no. 06-04-48113).

${ }^{8}$ Author for correspondence (e-mail: p.rudall@kew.org)
}

analyses (e.g., Qiu et al., 2006); inclusion of Hydatellaceae could further affect these results. Saarela et al.'s (2007) discovery allows us to reassess hypotheses concerning morphological evolution in flowering plants. It has prompted us to reevaluate the morphology (both vegetative and reproductive) of Hydatellaceae, which was hitherto poorly known for many important morphological characters. Some features are unknown, and others have previously been investigated in only a single species. Thus, a detailed morphological comparison between Hydatellaceae and other early-divergent angiosperms is urgently required.

Hydatellaceae are inconspicuous, aquatic, predominantly annual herbs (Fig. 1). Currently little is known about their pollination biology, but because reproductive units may develop either within or just above the water, pollination is normally assumed to be abiotic, either by wind or by water. As currently (imperfectly) circumscribed, the family includes two genera: Hydatella Diels, with four species from Australia and one (H. inconspicua Cheeseman) from New Zealand, and Trithuria Hook. f., with three species from Australia and one (T. konkanensis S.R. Yadav \& Janarth.) from India (Cooke, 1987; Yadav and Janarthanam, 1994; Hamann, 1998). Although generic boundaries require review (Sokoloff et al., in press), Trithuria is broadly characterized by bisexual reproductive units and usually dehiscent fruits with three prominent longitudinal ribs, whereas Hydatella typically has unisexual reproductive units and indehiscent fruits lacking distinct ribs (Cooke, 1987; Hamann, 1998). Because of their extremely small size and narrow linear leaves, Hydatellaceae are readily confused with other small aquatics, especially the 


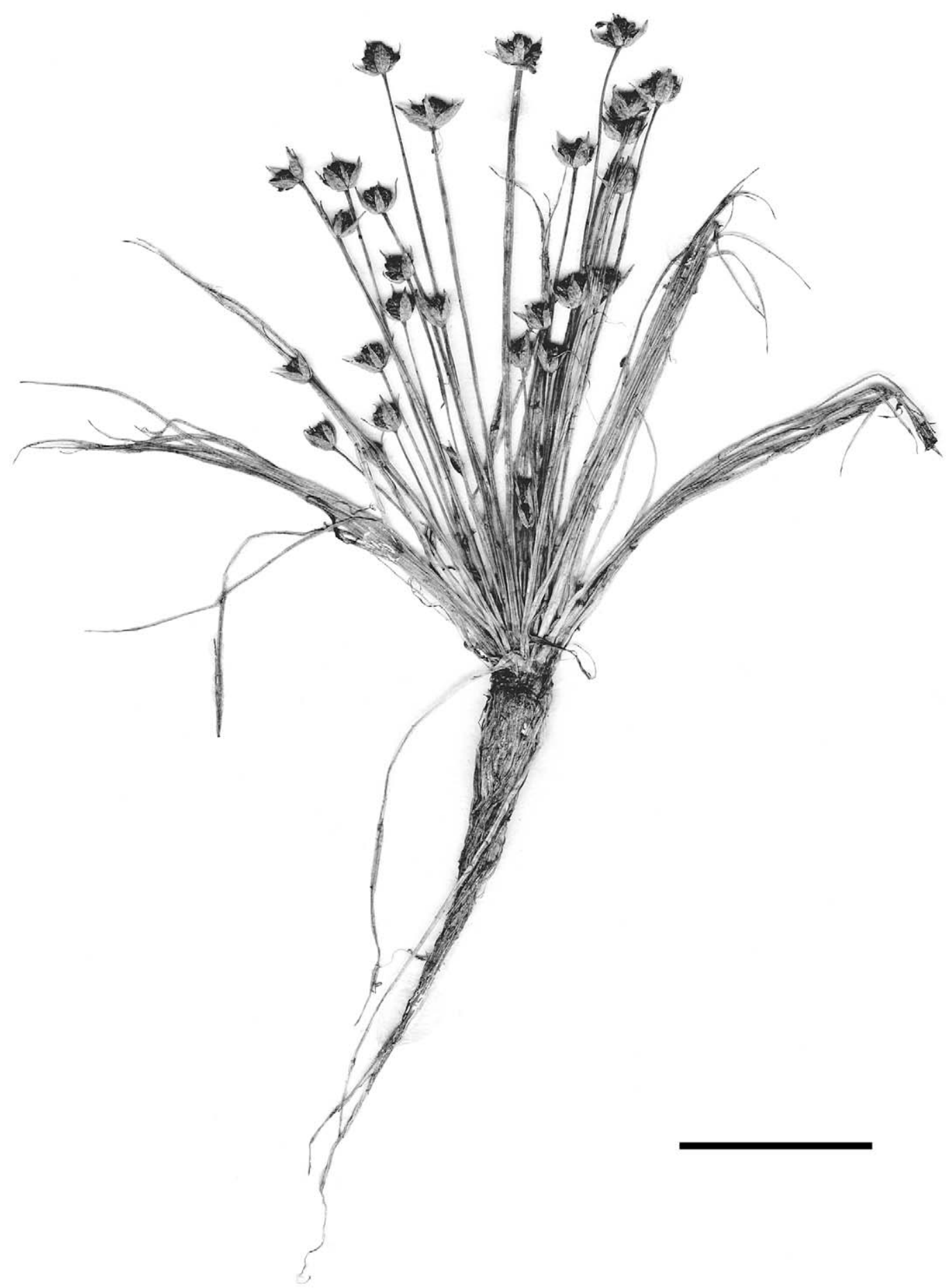

Fig. 1. Trithuria submersa, entire plant scanned from specimen at K: Melville 2217 (from Callum Downs, Victoria, Australia, 6 December 1952 ). Scale bar $=1 \mathrm{~cm}$.

monocot family Centrolepidaceae, in which they were previously placed (e.g., Hieronymus, 1888; Diels and Pritzel, 1904; Wettstein, 1924; Hamann, 1962, 1975; Edgar, 1966). Many samples that we have studied actually represent a mixture of the two families, highlighting the problem of identification of plant material for both morphological analysis and DNA extraction.
The radically revised taxonomic placement of Hydatellaceae resurrects the much-debated question of whether any nonmolecular characters could allow confident assignment to, or exclusion from, monocots-an issue that was earlier discussed with respect to Acorus, the putative sister of all other monocots (Grayum, 1987; Rudall and Furness, 1997; Buzgo and Endress, 2000). Furthermore, Hydatellaceae differ significantly from 
other early-divergent angiosperms, so their new taxonomic assignment could challenge current views on patterns of morphological evolution in angiosperms.

Finally, this investigation offers an opportunity to address contrasting hypotheses on the morphological identity of the unusual reproductive structures of Hydatellaceae, in comparison with those of other early-divergent angiosperms. Reproductive units of Hydatellaceae are usually described as compact aggregations (pseudanthia) of perianthless unisexual flowers, each male flower consisting of a single stamen and each female flower a single pistil with a unilocular carpel enclosing a single ovule. However, Hamann (1976) was ambivalent about whether each pseudanthium represents a simple or compound inflorescence. Equally, it is not clear whether each pistil represents a single carpel or a pseudomonomerous gynoecium. Each reproductive unit is surrounded by two or several involucral bracts, but individual stamens and pistils are not subtended by bracts. As previous interpretations were influenced by the supposed phylogenetic placement within Poales, we use more neutral terminology such as "reproductive unit" rather than pseudanthium or (partial) inflorescence in the descriptive part of this paper and directly address the question of morphological identity only in the Discussion.

\section{MATERIALS AND METHODS}

\begin{abstract}
Material - We examined four separate collections of alcohol- and FAAfixed material of Hydatellaceae: (1) Trithuria submersa Hook. f. collected by A. Doust 1123, J. I. Davis, and D. W. Stevenson (voucher deposited at MELU), South Australia, November 1998. This material, consisting of more than 20 individuals, each with numerous reproductive units, was used for morphological observations and sectioning for light microscopy (LM: Figs. 2, 3A-D). (2) Trithuria submersa collected by $J$. G. Conran 961 and P. J. Rudall (voucher deposited at ADU), 3 November 1998 near Bangham Conservation Park, South Australia, in seasonally ephemeral swamp. This material (about 30 individuals, some of them with numerous reproductive units) was used for scanning electron microscopy (SEM) and observations of reproductive morphology (Figs. 3-7). (3) Trithuria lanterna D. A. Cooke collected by C. R. Dunlop 4740A (voucher deposited at K), Northern Territory, Australia, 18 March 1978. This material (about 15 individuals, each with one to three reproductive units) was used for SEM examination (Fig. 8). (4) Hydatella australis Diels collected by $T$. D. Macfarlane and R. W. Hearn, TDM 3357, Western Australia 15 December 1999. This material (about 15 individuals, some of them with numerous reproductive units) was used for SEM and observations of reproductive morphology (Figs. 2J-M, 3E, H, 9, 10). We also examined 25 specimens of dried herbarium material of Hydatellaceae deposited at $\mathrm{K}$ (for complete list see Sokoloff et al., in press), and microscope slides used by Hamann (1975), including Hydatella inconspicua (Cheesem.) Cheesem. (Fig. $3 \mathrm{~F}, \mathrm{G})$.
\end{abstract}

Methods-All fixed material was transferred to $70 \%$ ethanol prior to examination. For SEM, material was dissected in $70 \%$ ethanol, then dehydrated through absolute ethanol and critical-point dried using a Balzers CPD 020 (BAL-TEC AG, Liechtenstein) at the Royal Botanic Gardens, Kew (RBGK). Dried material was further dissected and mounted onto specimen stubs using double-sided tape, coated with platinum using an Emitech K550 sputter coater (Emitech, Ashford, UK), and examined using a Hitachi cold field emission SEM S-4700-II (Hitachi High Technologies Corp., Tokyo, Japan) at RBGK. For LM observations, material was embedded in paraplast prior to sectioning at the New York Botanical Garden (NYBG) and RBGK. Fixed flowers and buds were dehydrated in an ethanol series to absolute ethanol. For wax sectioning, material was embedded using standard methods and sectioned using a Leica microtome (Leica, Wetzlar, Germany). Sections were stained in toluidine blue and mounted in DPX (distrene/dibutyl phthalate/xylene; Agar Scientific, UK). Digital photomicrographs were taken using a Leitz Diaplan photomicroscope (at RBGK) or a Zeiss Axioplan (Zeiss, Hallbergmoos, Germany) photomicro- scope (at NYBG). The optimization in Fig. 11 was performed using WinClada (Nixon, 2002).

\section{RESULTS}

One species, Trithuria submersa, is described in detail, based on two collections from South Australia. The other species are described for aspects that differ from T. submersa, though histological features were not examined for T. lanterna.

Trithuria submersa-Individual plants (Fig. 1) possess a rosette of linear foliage leaves, several peduncles, and numerous adventitious roots. Phyllotaxis in the basal parts of the plants varies from $2 / 5$ to $3 / 8$, apparently depending on the size of the plants. We found only one plant with eight orthostiches. Axillary buds, when present, give rise to inflorescences. Plants are hapaxanthic, because there are no renewal shoots, only inflorescences. No vegetative branches were observed.

The mature stem (Fig. 2A) consists of a uniseriate epidermis enclosing a parenchymatous cortex and pith, plus a vascular plexus composed of adventitious root traces alternating with leaf traces (Fig. 2D). The cortex has large intercellular spaces so that the parenchyma cells appear pegged (Fig. 2B, D), but air canals are absent. Adventitious roots arise endogenously at the nodes within the middle region of the cortex. The root consists of a rhizodermis composed of long and short cells (Fig. 2C), a uniseriate exodermis, a narrow parenchymatous cortex, an endodermis with Casparian thickenings, a uniseriate pericyle, and a single layer of sieve elements surrounding a single xylem element (Fig. 2B, C). Copious long root hairs are formed. Although there appear to be air canals in mature roots, these are actually enlarged endodermal cells with large vacuoles. The only true air canals in the entire plant are those in the leaves.

The inflorescence axis (Fig. 2E) consists of a uniseriate epidermis of axially elongated cells, a mostly uniseriate hypodermis that is two cells thick in places, a cortex composed of 3-4 layers of chlorenchyma, an endodermis with Casparian thickenings, and a uniseriate pericycle surrounding a single vascular bundle. Leaves are linear at maturity. Very young leaf primordia are circular in transverse section but ultimately become triangular as a result of limited marginal meristems that produce 2-4 pairs of derivatives at each margin and the differentiation of air canals (Fig. 2G-I). No apical precursor tip (forerunner tip or Vorläuferspitze, frequently observed in monocots: Rudall and Buzgo, 2002) was observed. The air canals are schizogenous in origin; no lysigenous stages were observed. The air canals of the leaves are not continuous into the stem (Fig. 2D). Mature leaves consist of a uniseriate epidermis, a uniseriate hypodermis, and mesophyll composed of single files of chlorenchyma between the large air canals (Fig. 2I). There is a single centrally located collateral vascular bundle surrounded by a single-layered chlorenchymatous bundle sheath. Stomata are anomocytic, and the elongated epidermal cells are not ornamented.

Reproductive units (Figs. 3A-D, 4) are bisexual. In our fixed material they terminate well-developed peduncles, though in some herbarium collections all peduncles are short, and reproductive units are sessile. Peduncle length is correlated with the age of the reproductive unit, so that the first-formed reproductive unit is easily recognized. In vigorous plants with 


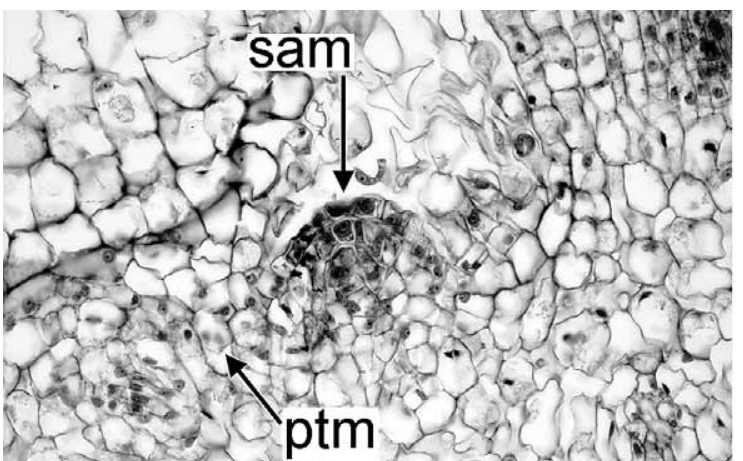
A 20.25
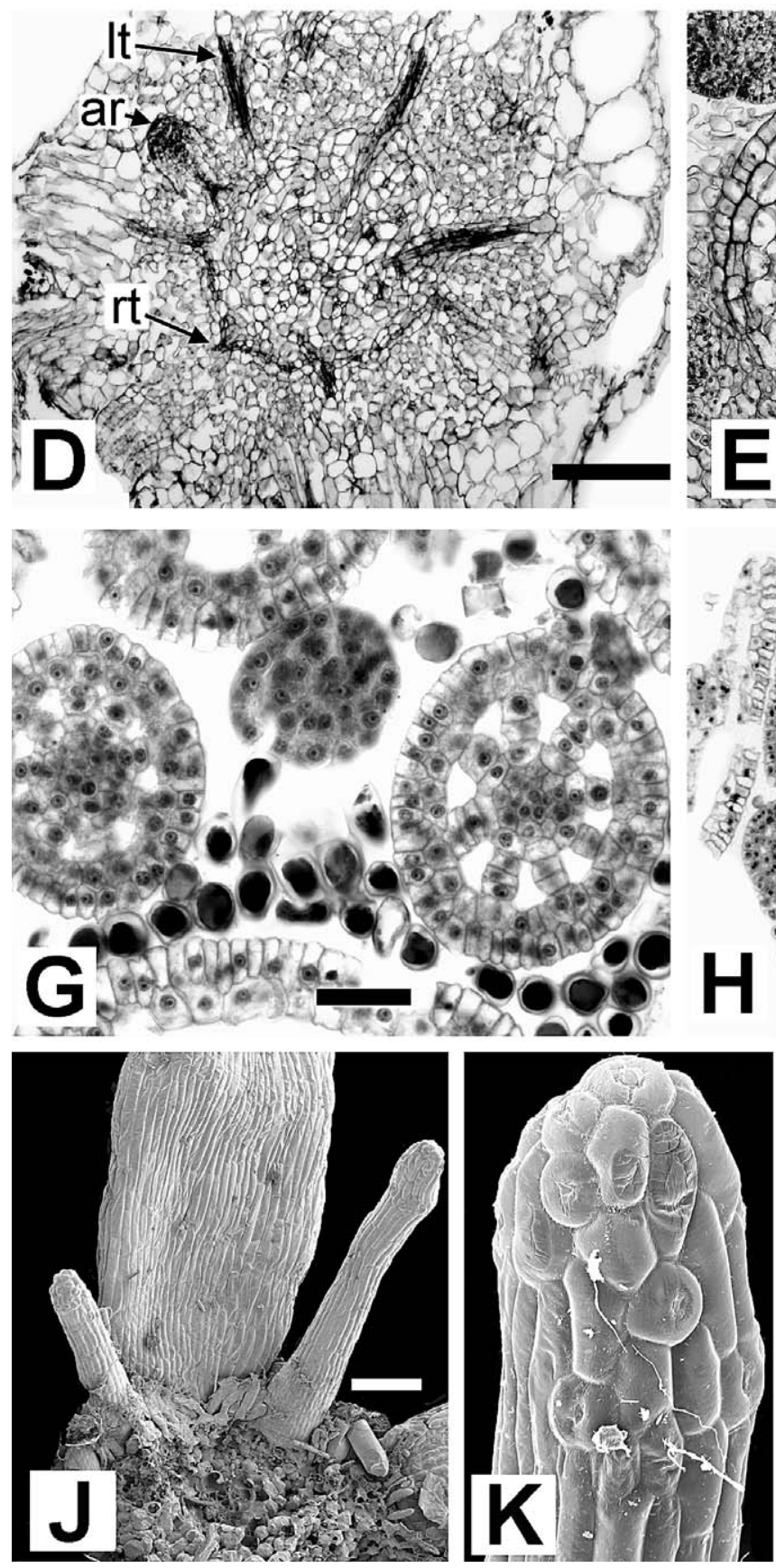

3) -1 $p$ or orb
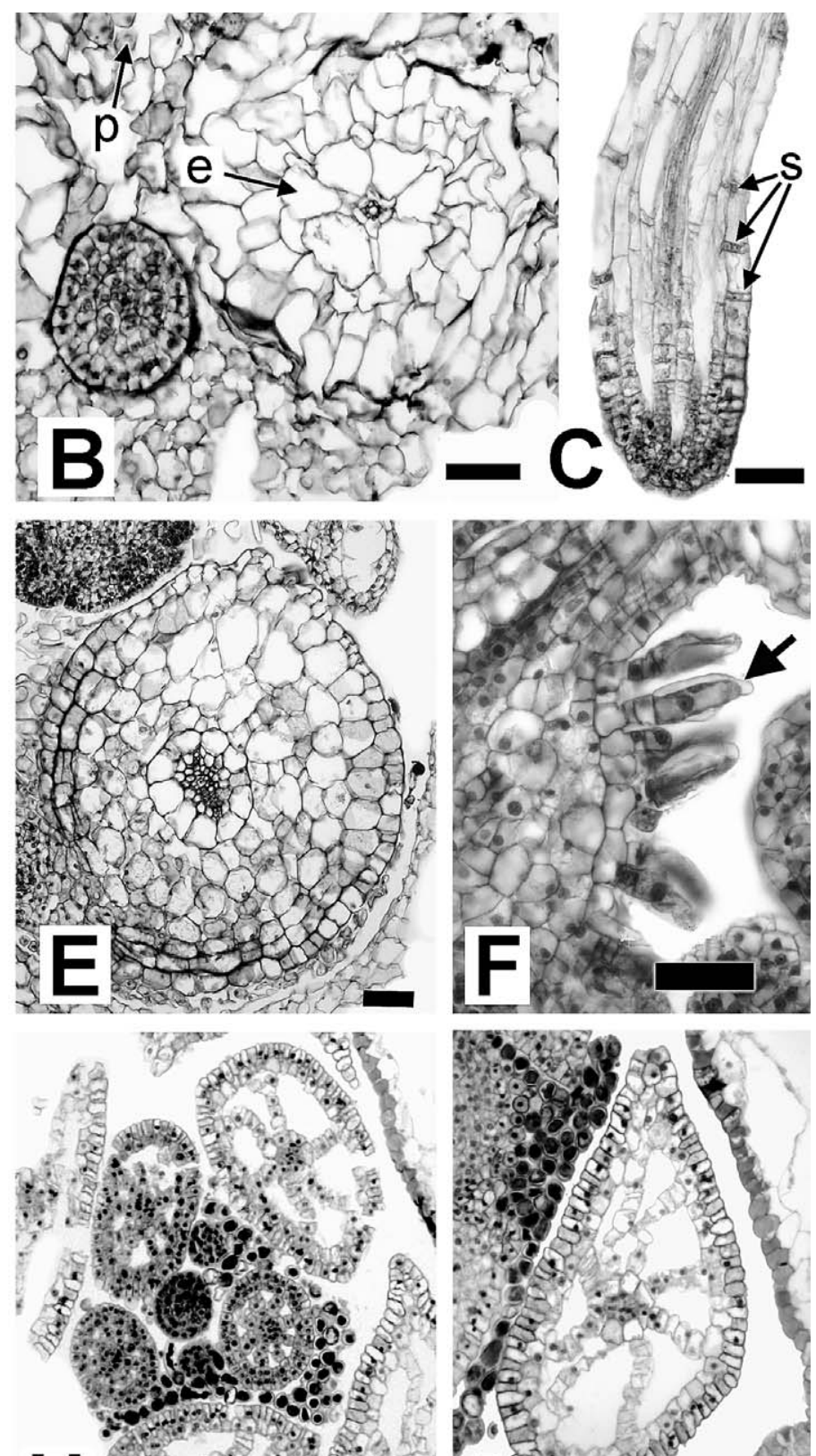

$\because 98,402 \div$ ?

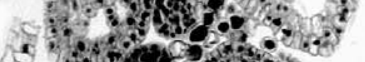
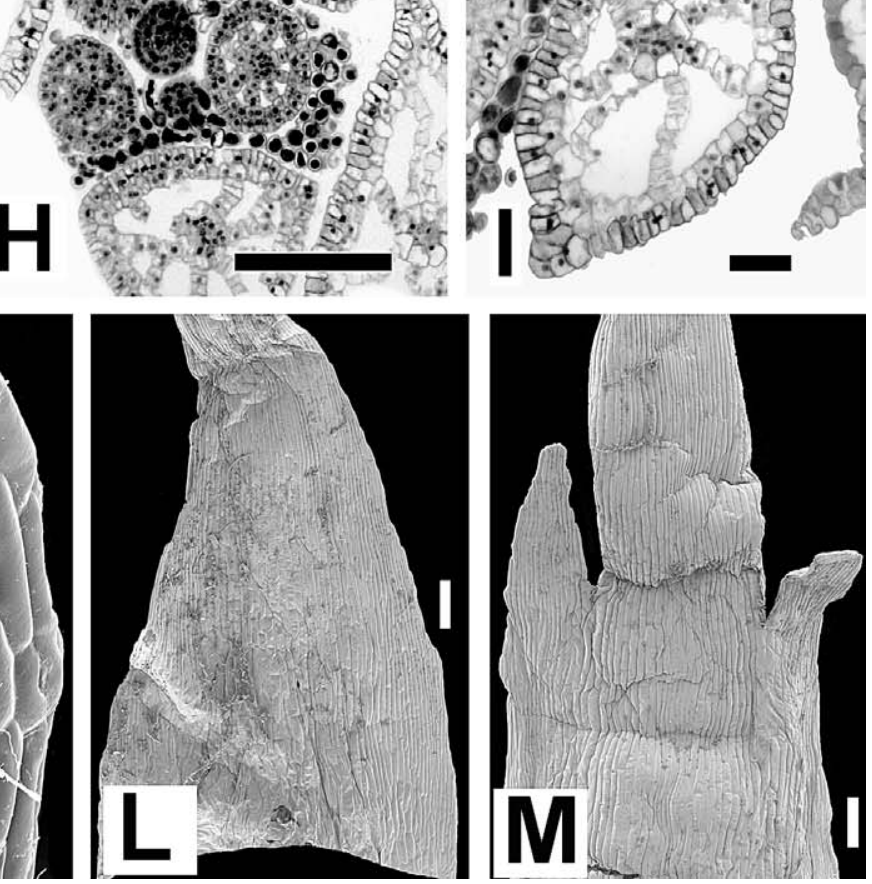
numerous leaves and peduncles, it is difficult to determine whether the first peduncle terminates the main axis of the plant. However, in plants with few peduncles this arrangement appears likely. Branching pattern is apparently cymose, with transverse prophylls. Two-keeled adaxial prophylls of the type that characterizes monocots and some magnoliids were never observed. It is likely that each lateral peduncle typically possesses two transverse prophylls, which were sometimes clearly visible during dissection of developmental material (Fig. 4A). These prophylls represent foliage leaves, though they are sometimes reduced and filiform. They subtend subsequent-order lateral peduncles, each also possessing transverse prophylls. However, one of the two prophylls is suppressed in some specimens, and branching does not necessarily occur. Furthermore, in vigorous plants some phyllomes are developmentally retarded and can be tiny bulges at the stage when the corresponding reproductive unit already possesses stamens and pistils.

Reproductive units possess stamens in the center and carpels in periphery (Figs. 3D, 4, 5A-C). As in the two other species examined here, the anther is basifixed and clearly differentiated from the elongated cylindrical filament, with a narrow connective (Fig. 3D, E). The thecae are symmetrically spaced, so that the anther is latrorse (Figs. 3E, 5A-C, 6I-L). The two longitudinal dehiscence slits extend along the entire length of the anther. As in the two other species examined, a group of large cells is present at the anther tip; these are already differentiated in preanthetic flowers. Each carpel bears a single apical ovule (Fig. 3A-D), as described by Hamann (1962, 1975, 1976, 1998). Carpel closure occurs by two surfaces being pressed together (Fig. 3C), leaving a very short narrow canal at anthesis, though this is difficult to determine except in good sections at the appropriate orientation. A style is lacking, and several unusual uniseriate stigmatic hairs are borne at the tips of each carpel (Fig. 3C, D).

In our fixed material, each reproductive unit possessed four (or sometimes three or five) involucral bracts and several pistils surrounding two (in one case three) central stamens (Figs. 4, 5A-C). Analysis of diverse herbarium collections of $T$. submersa shows that a few specimens possess up to eight involucral bracts, and a few possess up to five stamens. We have ontogenetic data only for reproductive units with four bracts and two stamens (Fig. 6). The four bracts clearly form two decussate whorls. The second whorl is considerably retarded in development with respect to the first whorl. During early ontogeny, the bases of the inner whorl bracts are much narrower than those of the outer whorl bracts, but this difference is no longer evident at anthesis, though the two successive whorls can still be recognized. (Because a perianth is lacking, we define anthesis as the time when stigmas are ready to receive pollen and/or anthers are ready to release it.) Early development of both inner and outer bracts is retarded with respect to development of stamens and pistils. We were unable to determine whether the inner-whorl bracts are initiated after formation of the stamens and first pistils, but they are extremely small and inconspicuous at early stages when some pistils are already developing (Fig. 6D-H).

Stamen initiation was not observed, but at an early stage the two stamens differ markedly in size and development (Fig. 6). The larger stamen occupies an almost central position in the reproductive unit; its future dehiscence lines are oriented approximately toward the inner-whorl involucral bracts. The second stamen lies between the first stamen and one of the outer-whorl bracts. The symmetry planes of the two stamens are more or less parallel to each other. The anthers are initially sessile, but just before anthesis the filament commences its considerable elongation. The two stamens usually open in succession. The anthers are abscised following anthesis, but the filaments remain attached to the reproductive unit. In the single case that we found with a third stamen (Fig. 4D), this was positioned close to the other two stamens in the center of the reproductive unit. However, the filaments of the two older stamens were already elongated, so it was not possible to compare their symmetry planes.

The first two pistils are initiated on opposite sides of the reproductive unit, alternating with the two stamens and approximately opposite the inner-whorl bracts (Fig. 6). These two pistils are smaller than the second stamen at early stages, but later outgrow it, though they remain much smaller than the first stamen. Further pistils are initiated in a centrifugal sequence (i.e., toward the involucral bract). Pistils do not form successive alternating whorls; rather, groups of pistils of successive ages apparently form zigzag patterns (Fig. 5A-D), though it is not always clear to which zigzag group some pistils should be assigned.

Pistils develop as pronouncedly ascidiate structures lacking a style and bearing several apical stigmatic hairs. Their opening is elongate and oriented radially (i.e., between the stamens and involucral bracts) (Figs. 3A-C, 6). The first stigmatic hair is usually initiated near the end of the elongate opening closest to the stamens (Fig. 3D). The second stigmatic hair appears close to, but considerably later than, the first one. At this stage, the triquetrous nature of the pistil is recognizable.

The fruit is markedly triquetrous, with three prominent ribs. At dehiscence, the ribs curve and separate from the rest of the pericarp, but they can remain attached to the distal part of the fruit (Fig. 7A-D). The fruit valves always remain distally connected to each other. Seeds are ovoid, with the raphe ridge not visible externally. A micropyle was not discernible in our material using SEM. The surface of the seed is composed of large, equiaxial or slightly transversally elongated, pentagonal or hexagonal exotestal cells (Fig. 7D-F), which form clear axial rows along the seed. Exotestal cells are convex in fixed material that has been critical-point dried (Fig. 7E, F), but

Fig. 2. Vegetative tissues in Trithuria submersa, LM (A-I), and Hydatella australis, SEM (J-M). (A) Longitudinal section (LS) of vegetative shoot through apical meristem showing rudimentary primary thickening meristem near shoot apex. (B) Transverse section (TS) through adventitious roots of different ages in stem cortex (older root on right with well-developed endodermis and central vascular tissue). (C) LS of root apex; epidermal cells dimorphic. (D) TS of stem showing vascular plexus composed of five adventitious root traces alternating with five leaf traces. (E) TS of inflorescence axis showing endodermoid layer. (F) Short glandular hairs (arrowed) between pistils and involucral bracts. (G, H) TS of leaves of various ages, showing development of air canals and phyllotaxy. (I) TS of mature leaf. (J) SEM of two prophylls at leaf base. (K) SEM of prophyll tip showing stomata. (L, M) SEM of two different leaf bases from a single plant showing variation in leaf shape. ar, adventitious root; e, endodermis; lt, leaf trace; p, pegged parenchyma cells in cortex; ptm, primary thickening meristem; rt, root trace; sam, shoot apical meristem; s, short cells alternating with long cells in dimorphic root epidermis. Scale bars $=25 \mu \mathrm{m}(\mathrm{A}-\mathrm{C}, \mathrm{E}-\mathrm{G}, \mathrm{I}), 125 \mu \mathrm{m}(\mathrm{D}, \mathrm{H})$, and $100 \mu \mathrm{m}(\mathrm{J}-\mathrm{M})$. 

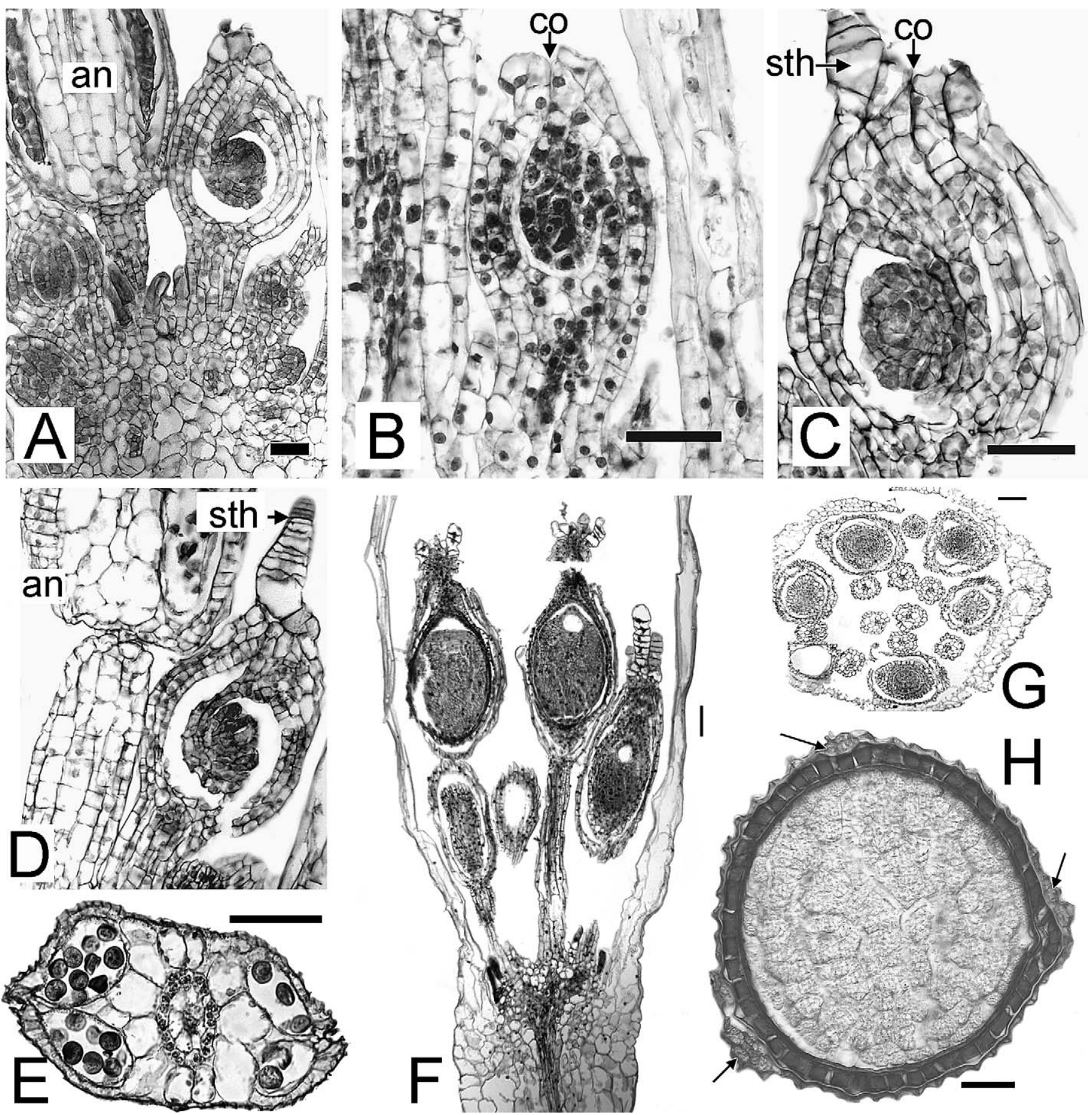

Fig. 3. Light micrographs (LM) of reproductive tissues of Trithuria submersa (A-D), Hydatella australis (E, H), H. inconspicua (F, G). (A-D) Longitudinal section (LS) of young reproductive units, each carpel bearing a single ovule at megaspore mother cell stage. Carpel closure occurs by two surfaces being pressed together (C). (E) TS of preanthetic anther with two thecae and a single vascular bundle showing latrorse dehiscence. (F) LS of entire reproductive unit showing several carpels (female flowers) on long pedicels. (G) TS of reproductive unit with several carpels. (H) TS of single carpel, with copious perisperm and three equally spaced ribs (arrows), each probably containing vascular bundles. an, anther; co, carpel opening; sth, stigmatic hair. Scale bars $=10 \mu \mathrm{m}(\mathrm{A}-\mathrm{D}, \mathrm{F}-\mathrm{H})$ and $50 \mu \mathrm{m}(\mathrm{E})$.

concave in dried herbarium material. Cells on the surface of the columnar structure are smaller and their outer walls are not convex (Fig. 7E).

Apart from the stigmatic hairs, two different trichome types occur in $T$. submersa and other Hydatellaceae. (1) Long trichomes are attached to the stem close to the leaf axils so that they appear axillary (Fig. 9A). (2) Short multicellular hairs develop between the stamen, pistils, and involucral bracts (Figs. 2F, 8B, 9E). These hairs are initiated early in development; they are already well formed at the youngest 

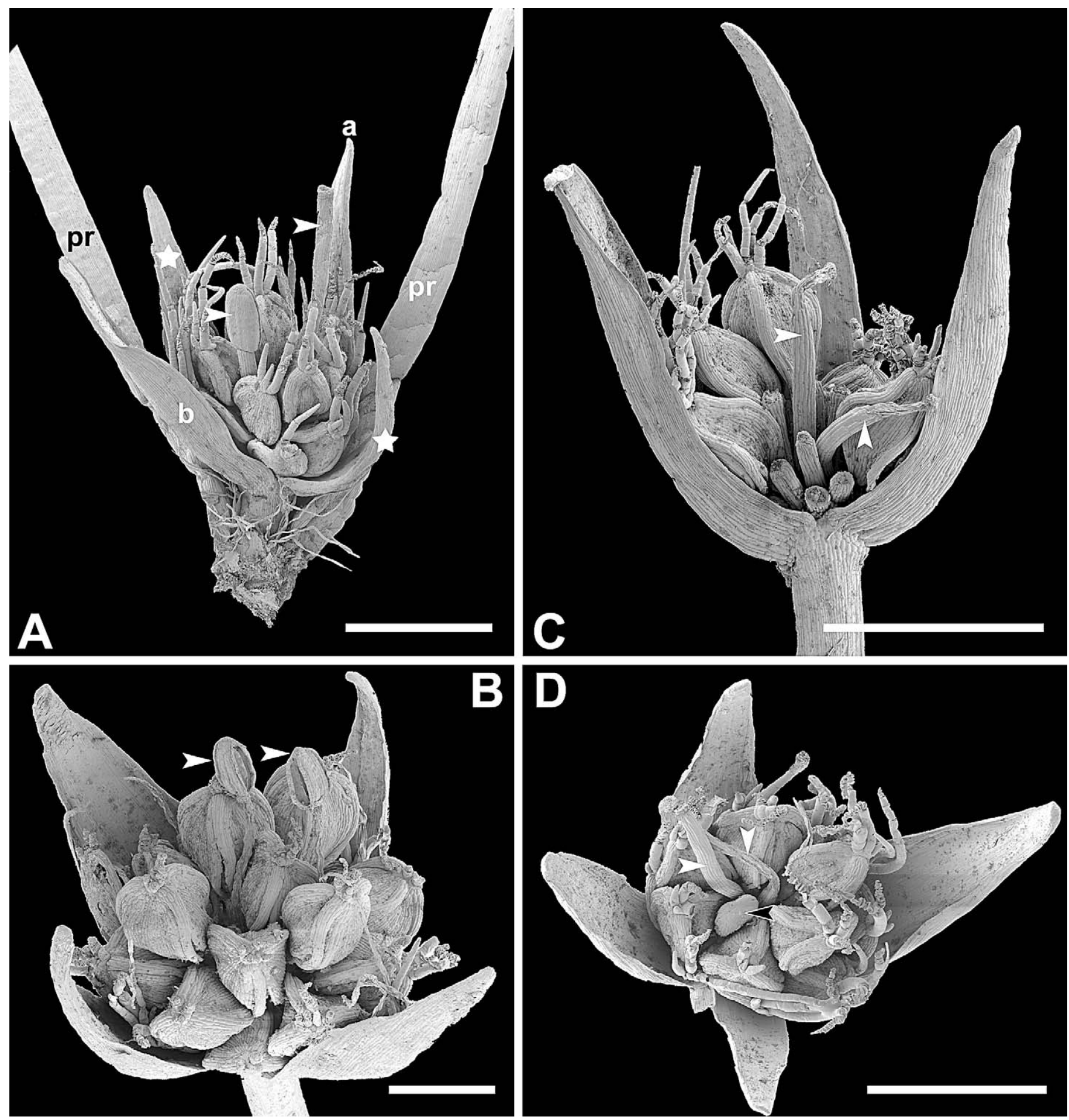

Fig. 4. SEM of anthetic and postanthetic reproductive units of Trithuria submersa. (A) Anthetic reproductive unit with two prophylls (pr) on its peduncle; $a, b=$ outer whorl involucral bracts; stars indicate inner whorl involucral bracts; white arrowhead indicates filament of first-formed stamen (anther abscised); black arrowhead indicates second-formed stamen (anther not yet dehisced). (B) Top view of typical postanthetic reproductive unit with four involucral bracts, two stamens (arrowheads), and several fruits, some of them already dehisced. (C) Unusual reproductive unit with three (rather than four) involucral bracts; two stamens are present, their filaments indicated by arrowheads. Four stipes of fallen mature fruits are visible in front of the figure. (D) Unusual reproductive unit with three stamens; white arrowheads indicate filaments of first- and second-formed stamens; black arrowhead indicates third-formed stamen. Scale bars $=1 \mathrm{~mm}(\mathrm{~A}, \mathrm{C}, \mathrm{D})$ and $500 \mu \mathrm{m}(\mathrm{B})$. 


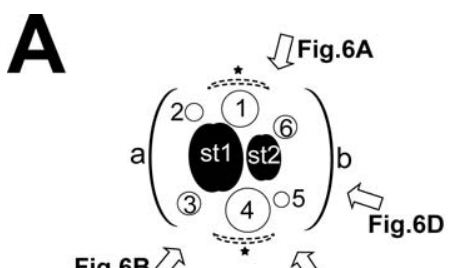

Fig.6B $\triangle$ Fig.6C

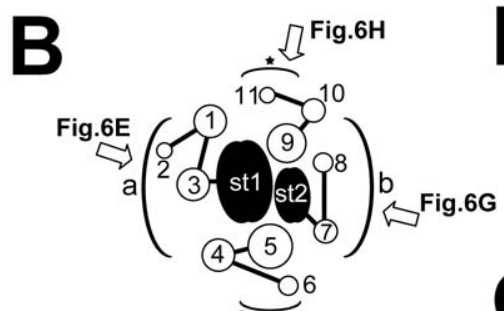

c Fig. $6 \mathrm{~F}$

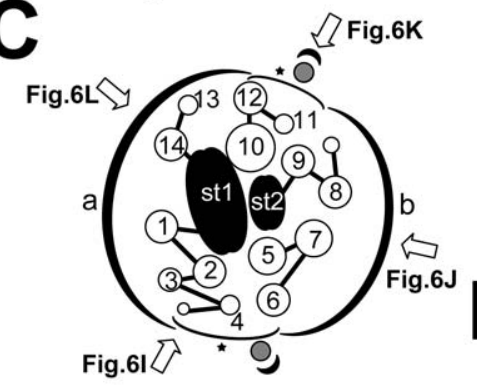

D
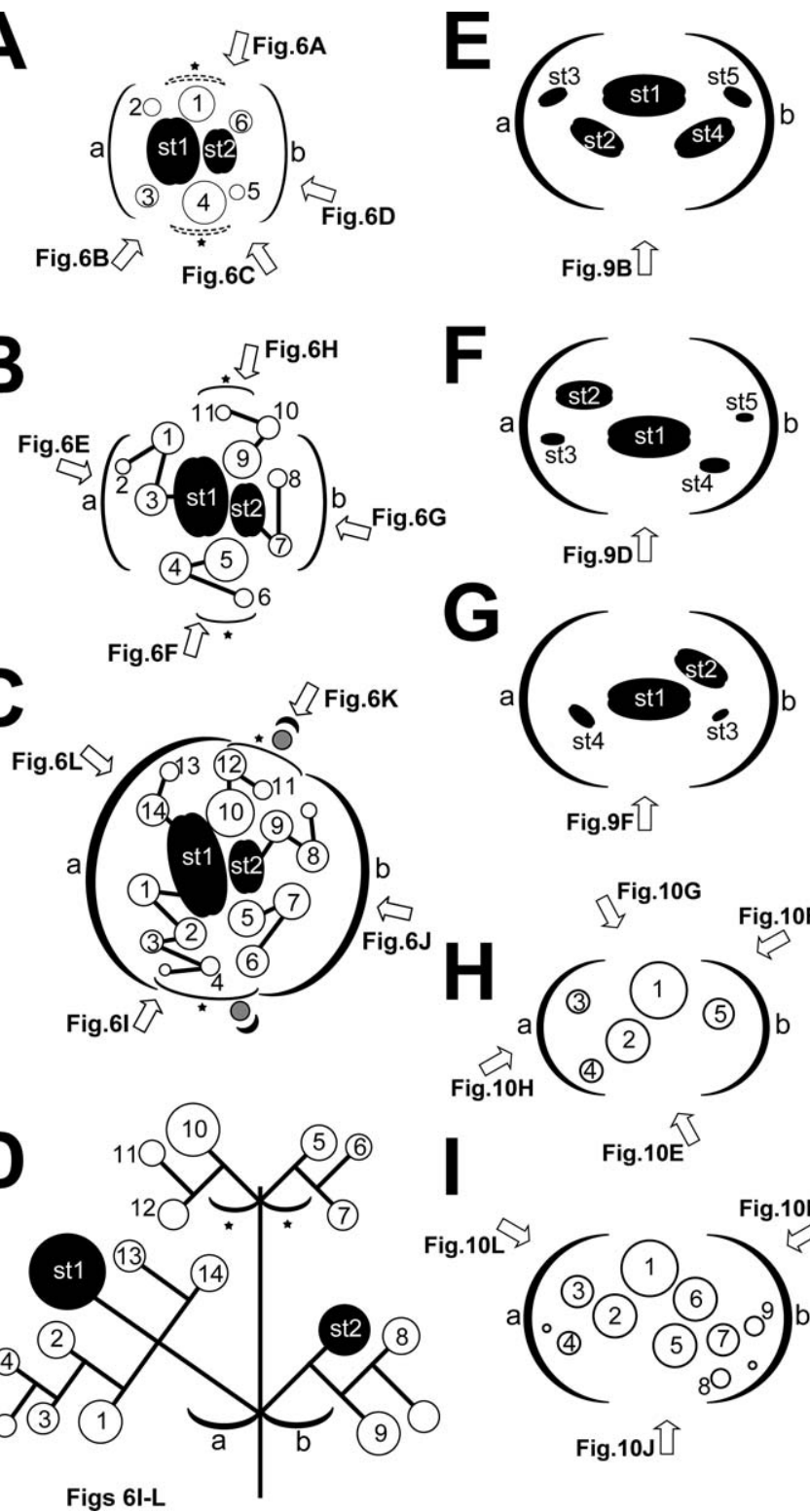

Fig.98

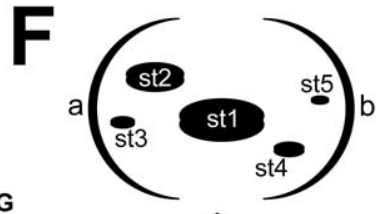

Fig.9D
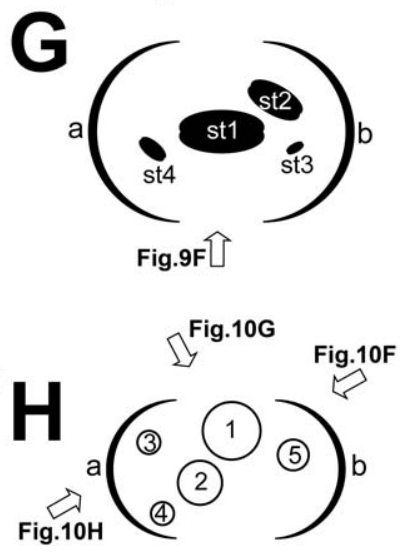

Fig.10H

Fig.10E

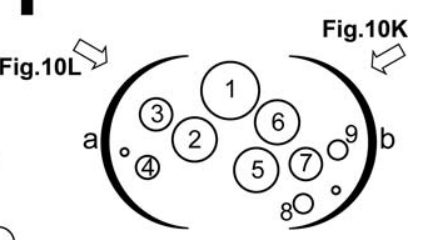

Fig.10J

Fig. 5. Diagrams of floral organization of (A-D) Trithuria submersa, (E-I) Hydatella australis. (A-C, E-I) Reproductive units at various developmental stages (Figs. 6, 9, 10). (D) Scheme for possible interpretation of diagram $\mathrm{C}$, with flower arrangement in cymose groups. Black ellipses, bracts; dotted ellipses, recently initiated bracts whose position is not yet completely clear; black ovals, stamens; open circles, pistils; gray circles, young lateral inflorescences. Interpretative scheme: black circles, stamens; white circles, pistils. Arrows and letters indicate sides from which images in Figs. 6, 9, and 10 were obtained. a, b, outer whorl bracts; stars, inner whorl bracts; arabic numbers, pistils (numbers do not show initiation sequence but position of the same pistils in SEM images and diagrams); st1, st2, etc., stamens.

stages of reproductive units and persist until fruit dehiscence. Each hair consists of one to three short basal cells and a longer (possibly secretory) terminal cell, that is rounded at the tip.

Trithuria lanterna (Fig. 8)-Most individuals that we examined possess a single reproductive unit that terminates the main axis of a plant. Some individuals also bear lateral reproductive units. Each reproductive unit has two linearlanceolate involucral bracts approximately $2 \mathrm{~mm}$ long, up to 10 pistils, and a single central stamen with an elongate filament and an anther up to $0.5 \mathrm{~mm}$ long.

In the earliest stages observed here (Fig. 8A-C), involucral bracts were already massive, well differentiated, and approximately $1.5 \mathrm{~mm}$ long. The anther was approximately $0.3 \mathrm{~mm}$ long with well-differentiated thecae but a very short filament; however, the pistils were at early developmental stages, some of them apparently not yet initiated. Young pistils were observed on opposite sides of the central stamen. They initiate and develop in succession, forming a zigzag pattern between a stamen and an involucral bract, so that the general pattern of pistil initiation within the reproductive unit is centrifugal. Pistils are initiated as clearly ascidiate structures. They are radially symmetrical at early developmental stages. Soon after their ascidiate nature becomes recognizable, uniseriate stigmatic hairs are initiated in succession, the first one usually on the side closest to the anther. Cells of the stigmatic hairs elongate considerably by anthesis. Cell elongation proceeds in an acropetal direction, so that at anthesis some non-elongated cells may remain at the tip of the stigmatic hair. Anthetic pistils are shortly stipitate and possess up to five stigmatic hairs that are up to up to $3 \mathrm{~mm}$ long and 10 times longer than the ovary. Stigmatic hairs persist after anthesis and remain attached to the young fruit. Fruits are approximately $0.3 \mathrm{~mm}$ long, with three equally spaced, prominent, longitudinal ribs containing vascular strands (Fig. 8F, G). When the fruit is mature, each rib curves (probably hygroscopically) and separates from the rest of the pericarp, which in our material remained associated with the seed. The seed surface is smooth, with cell margins almost unrecognizable.

Hydatella australis (Figs. 2J-M, 3E-H, 9, 10)—A rosette of numerous linear vegetative leaves surrounds a central cluster of reproductive units, in which vegetative leaves are either short or suppressed. In our material the annual habit was demonstrated by the frequent presence of remnants of a seed coat at the base of the leaf rosette, even in vigorous plants bearing numerous reproductive units and leaves. Leaves are linear with a dilated base, either with or without two auricles (Fig. 2L, M). Stomata are absent except at leaf tips (Fig. 2K).

Individuals available for this study possess a male unit in the center of a cluster of short-stalked or sessile reproductive units, though it is not entirely clear whether the male unit terminates the main axis. Other reproductive units are mostly female, though in vigorous individuals a few of the youngest peripheral units are also male. The branching pattern within the cluster of reproductive units is cymose, but sometimes difficult to interpret. In some material we clearly observed lateral shoots with two almost transverse prophylls (Fig. 2J, K) and a terminal reproductive unit; in some specimens the prophylls generate further reproductive units in their axils. Prophyll size is variable, and sometimes only one transverse prophyll is present, the second having been suppressed.

Male reproductive units possess two (rarely three) involucral bracts surrounding the stamens (Figs. 5E-G, 9). Each stamen has an elongate filament bearing an anther $0.6-0.7 \mathrm{~mm}$ long. Stamens are initiated and develop in succession within each reproductive unit. The first stamen initiated occupies an almost terminal position. Subsequently, two groups of stamens are initiated on either side of the first. Within each group, stamens are initiated centrifugally (i.e., toward the involucral bract) and 

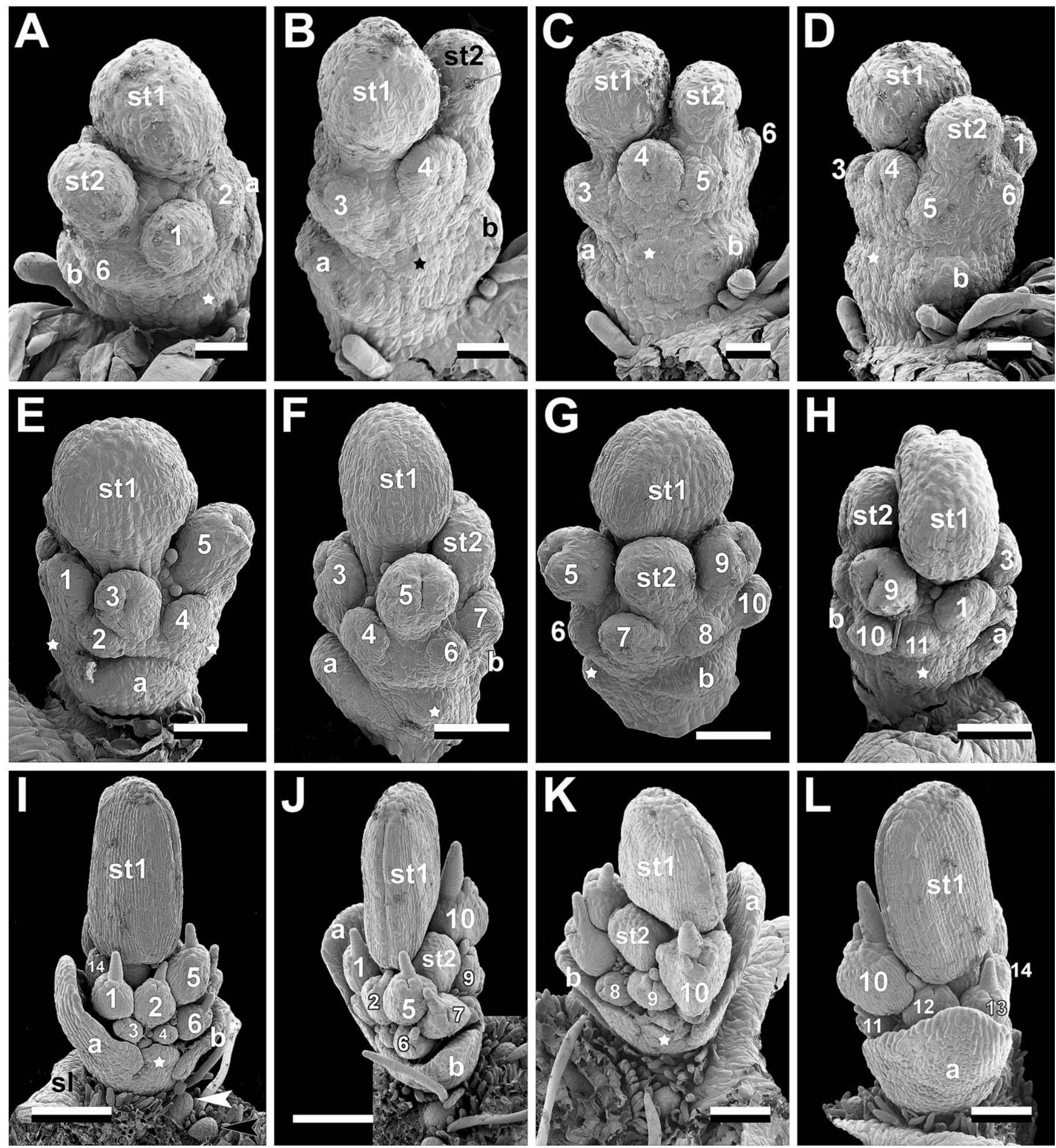

Fig. 6. SEM of reproductive units of Trithuria submersa. (A-D) Different rotational views of the same reproductive unit (B, rotated $140^{\circ}$ against A; C, $60^{\circ}$ against $\mathrm{B} ; \mathrm{D}, 60^{\circ}$ against $\mathrm{C}$ ). (E-H) Different views of the same reproductive unit (rotation angle $90^{\circ}$ from previous image). (I-L) Different views of the same reproductive unit (rotation angle $90^{\circ}$ from previous image). sl, subtending leaf of reproductive unit, mostly removed; black arrowhead, one of two prophylls on peduncle of reproductive unit; white arrowhead, very young subsequent-order reproductive unit in axil of prophyll; other labels as in Fig. 3 . Scale bars $=25 \mu \mathrm{m}(\mathrm{A}-\mathrm{D}), 50 \mu \mathrm{m}(\mathrm{E}-\mathrm{H}), 100 \mu \mathrm{m}(\mathrm{K}, \mathrm{L})$, and $150 \mu \mathrm{m}(\mathrm{I}, \mathrm{J})$. 

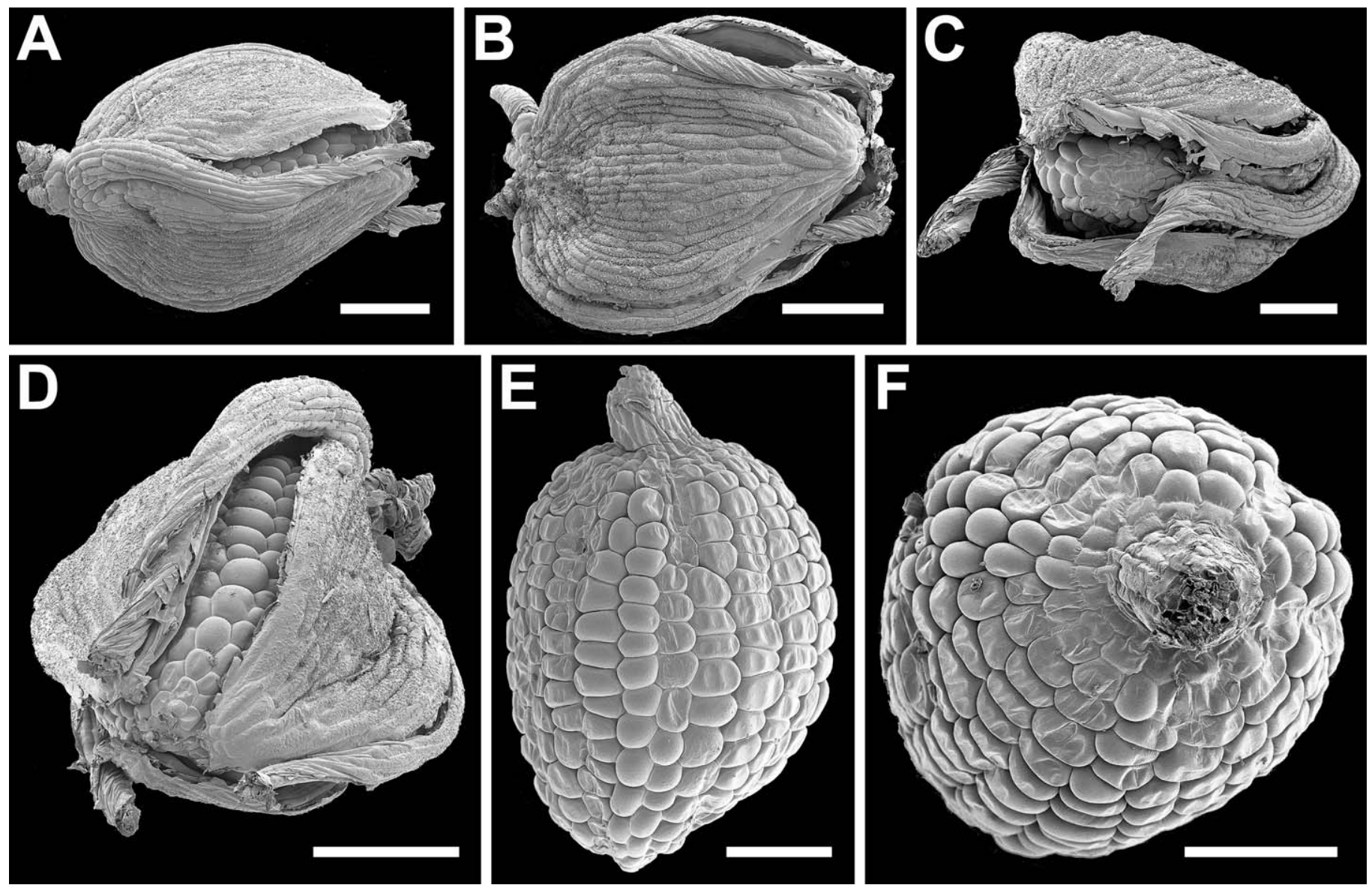

Fig. 7. SEM of Trithuria submersa, dehiscent fruits (A-D) and seeds (E-F). (A, B) Lateral views of fruits; proximal side to the right, bases of collapsed stigmatic papillae to the left in both figures. (C, D) Views of fruits from proximal side. (C) An unusual fruit with two veins very close to each other (to the right of the figure). The third vein is on the opposite side of the fruit. (D) Typical fruit with three equally spaced veins, each separating from neighboring tissues due to hygroscopic curvature. Note seed surface partly visible in A, C, and D. (E) Side view of seed. (F) View of seed from micropylar side. Scale bars $=150 \mu \mathrm{m}(\mathrm{A}, \mathrm{B}, \mathrm{D})$ and $100 \mu \mathrm{m}(\mathrm{C}, \mathrm{E}, \mathrm{F})$.

form a zigzag pattern. In some inflorescences, both groups contain the same number of stamens (e.g., two or three); in others, one group is represented by a solitary stamen.

Female reproductive units (Figs. 5H, I, 10) possess two (rarely three) involucral bracts surrounding individual pistils. The first pistil is initiated either in the center of the reproductive unit or is shifted laterally in the plane between the two bracts. The two subsequent pistils are initiated simultaneously or in succession. They occur between the first pistil and each of the involucral bracts, shifted laterally with respect to the first pistil in the plane between the two bracts. At subsequent stages, more pistils are initiated centrifugally (toward the involucral bracts). Two sets of pistils of successive ages forming zigzag patterns can often be recognized, but in some plants one group is represented by a solitary pistil, or the pattern of pistil arrangement is more complex. Pistil development is completely ascidiate, closely resembling that of Trithuria. A transverse section of an immediately preanthetic carpel (Fig. 3H) shows a thin carpel wall with three equally spaced ribs probably containing vascular bundles; the nucellar tissue (perisperm) is already massive at this stage.

\section{DISCUSSION}

Hydatellaceae possess both monocot-like and dicot-like features-As Hamann (1976) demonstrated, microscopic examination reveals considerable disparity between Hydatellaceae and Centrolepidaceae, the monocot family with which it regularly co-occurs and in which it was formerly placed. Numerous morphological differences were outlined previously (e.g., Hamann, 1962, 1975, 1976, 1998; Bortenschlager et al., 1966; Cutler, 1969; Hamann et al., 1979; Linder, 1987) and substantiated here using additional species. These characters include stomata (anomocytic in Hydatellaceae vs. paracytic in Centrolepidaceae), anther (tetrasporangiate and basifixed vs. bisporangiate and versatile), pollen (monosulcate vs. monoporate), ovules (anatropous vs. orthotropous), several unusual stigmatic hairs that were formerly interpreted as styles (vs. a single style in Centrolepidaceae), and several characters of the seed and seed coat (discussed later). In addition, seed germination in Hydatellaceae is reportedly hypogeal without an exposed cotyledon (at least in Trithuria: Cooke, 1983), vs. (in Centrolepidaceae) hypogeal with the seed raised above ground on the tip of a single green cotyledon (Hieronymus, 

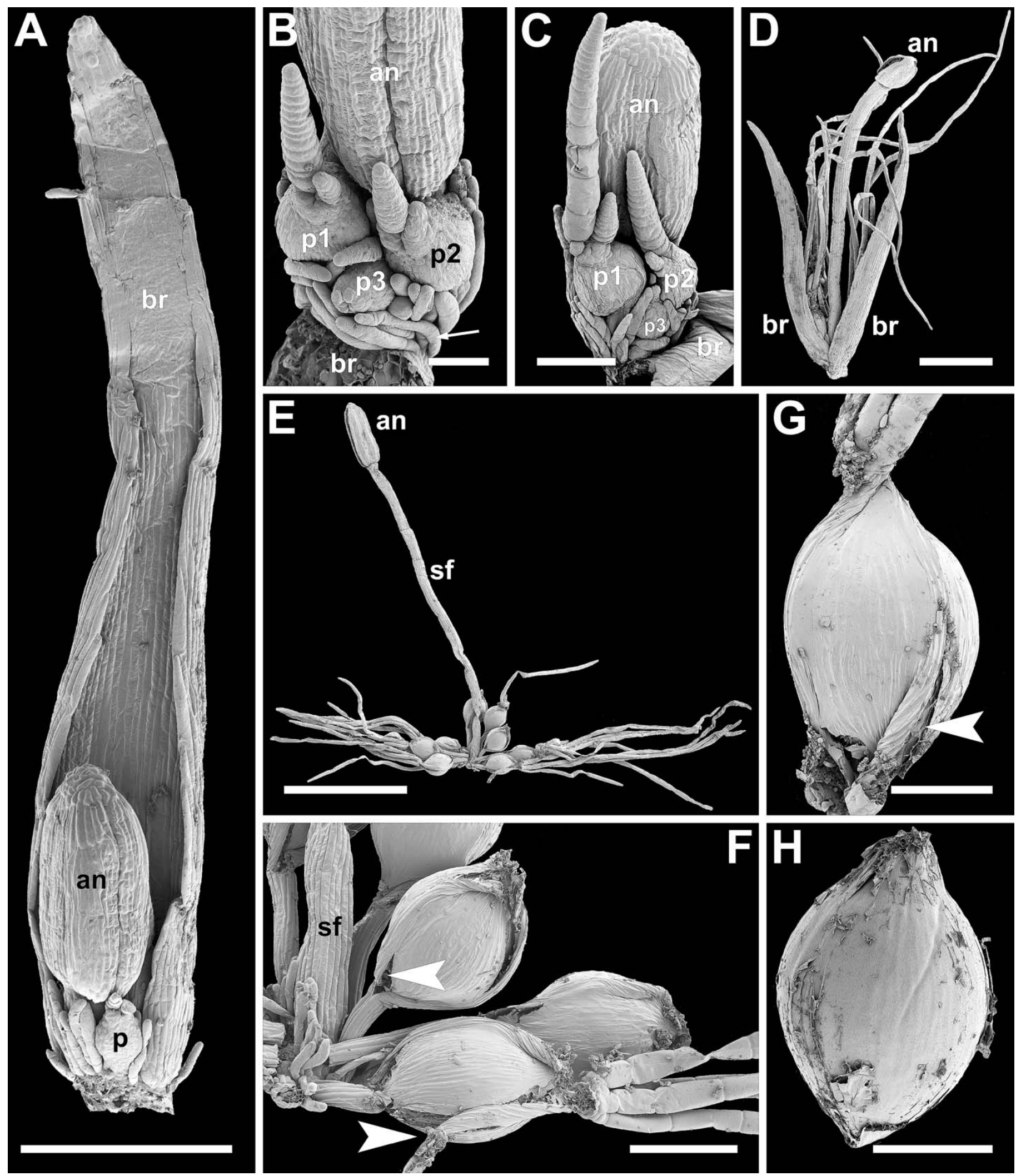

Fig. 8. SEM of Trithuria lanterna, bisexual reproductive units and fruits. (A-C) Successive developmental stages of reproductive unit, lateral views; short glandular hairs arrowed in B. (One of two involucral bracts removed in A; both involucral bracts removed in B and C.) (D) Recently postanthetic reproductive unit; note very long stigmatic papillae that are longer than the stamen. (E) Reproductive unit with mature fruits; note persistent stigmatic papillae. $(\mathrm{F}-\mathrm{H})$ Fruits and seed from the unit illustrated in E. (F, G) Dehiscent fruits (arrowheads indicate places of dehiscence). (H) Seed with pericarp removed. an, anther; br, involucral bract; $p$, pistils $(1,2,3=$ sequence of initiation); sf, stamen filament. Scale bars $=250 \mu \mathrm{m}(\mathrm{A}), 50 \mu \mathrm{m}(\mathrm{B}), 100 \mu \mathrm{m}$ (C, G, H), $500 \mu \mathrm{m}$ (D), $1 \mathrm{~mm}(\mathrm{E})$, and $150 \mu \mathrm{m}(\mathrm{F})$. 

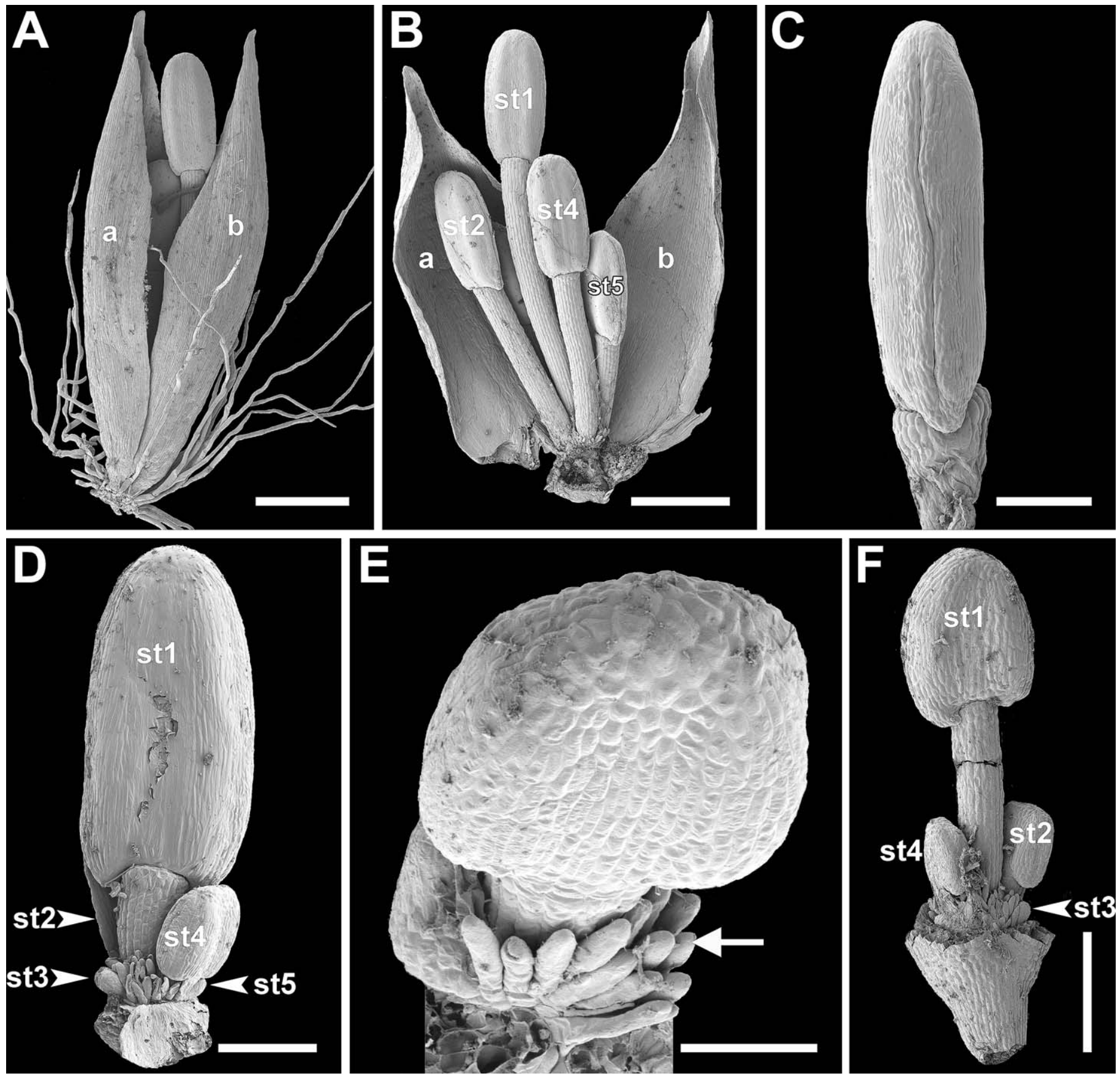

Fig. 9. Hydatella australis, male reproductive units. (A) Lateral view of preanthetic reproductive unit with two involucral bracts. Long hairs are attached to the stalk below the unit. (B) Preanthetic reproductive unit with both bracts partially removed to show stamens. (C) Anther from the side of the dehiscence line. (D) Young unit with both bracts removed. (E) Young unit viewed from above showing large cells at the distal region of the largest stamen; short glandular hairs arrowed. (F) Young unit with both bracts removed (they were located to the left and right of the current view). a and b, involucral bracts; st1-st5, stamens. See Fig. 5 for diagrams of the same reproductive units with corresponding labels. Scale bars $=500 \mu \mathrm{m}(\mathrm{A}, \mathrm{B}), 150 \mu \mathrm{m}(\mathrm{C}, \mathrm{D}), 50$ $\mu \mathrm{m}(\mathrm{E})$, and $250 \mu \mathrm{m}(\mathrm{F})$.

1873). However, the number of cotyledons-the basic morphological character distinguishing monocots from other angiosperms - has not yet been properly documented in Hydatellaceae and will be the subject of further investigation. Hitherto, all nonmonocots with a single cotyledon belong in the eudicot clade (also termed the tricolpates), which is readily identifiable by several morphological characters, especially pollen (e.g., Furness and Rudall, 2004). Seedlings of Nymphaeaceae, formerly interpreted as monocotylar, are now widely considered to be dicotylar (e.g., Tillich, 1990).

In the absence of molecular data, few morphological characters (except cotyledon number) would allow confident 
exclusion of Hydatellaceae from monocots; most "monocot features" (e.g., monosulcate pollen and trimerous flowers) occur in both monocots and early-divergent angiosperms. Many of the features listed by Grayum (1987) linking Acorus (the putative sister to all other monocots) with early-divergent angiosperms (specifically the magnoliid order Piperales) have with hindsight been shown to be highly homoplasious, including presence of ethereal oil cells, orthotropous ovules, secretory anther tapetum, and cellular endosperm (Rudall and Furness, 1997). Stevenson and Loconte's (1995) morphological analysis of monocots placed Hydatella close to Acorus, based mainly on shared possession of perisperm. However, the dermal nonstarchy perisperm of Acorus is not homologous with the subdermal, starchy perisperm that characterizes Hydatella and other early-divergent angiosperms and monocots (Rudall and Furness, 1997; Rudall, 2000).

Similarly, some characters that are rare or absent in nonmonocots, such as ensiform leaves, hollow styles, and septal nectaries, are not present in all monocots, so their absence from Hydatellaceae is inconclusive. Linear leaves of Hydatellaceae are an unusual feature for early-divergent angiosperms, though they could be compared with the first seedling leaves of Nymphaeaceae (see Tillich, 1990). Linear leaves are also not uncommon among several groups of aquatic eudicots. Compared with any other plant group, Hydatellaceae are highly anomalous with respect to many characters. They lack crystals or silica bodies that could help to place them phylogenetically. The earlier report of minute, but otherwise typical, P2c-subtype plastids in well-documented Australian material of Hydatella (Behnke, 2000) could represent a remarkable and unique homoplasy, because protein type ( $\mathrm{P}$ type) sieve-element plastids characterize almost all monocots and a few early-divergent angiosperms (e.g., some Magnoliaceae) but not Nymphaeales, which have S-type plastids (Behnke, 1976). Furthermore, the typical monocot P2 subtype (with several triangular crystalloid bodies) is reportedly absent from all nonmonocots except Asarum and Saruma (Aristolochiaceae). This record for Hydatellaceae requires confirmation, as we have frequently found material of Hydatellaceae to be mixed with Centrolepidaceae. However, H. D. Behnke, University of Heidelberg (personal communication, 2006) noted that in his material, plastids of Hydatella are readily distinguishable from those of Centrolepis.

Nymphaeales also possess some features that are at least superficially monocot-like, especially in vegetative characters. This similarity, at least partly due to the shared aquatic habit (discussed later), makes the two groups difficult to effectively distinguish in the absence of molecular data. Hence, Nymphaeales are consistently allied with monocots in morphological cladistic analyses (Doyle and Endress, 2000) as well as in many earlier phylogenies (e.g., Takhtajan, 1966), an association based on several characters (e.g., absence of secondary growth). However, some "monocot-like" vegetative features of Nymphaeaceae are not homologous to those of monocots. For example, the occurrence of numerous randomly spaced vascular bundles visible in cross sections of the Nymphaea rhizome cannot be described as a monocot-like atactostele (Weidlich, 1976a, b, 1980).

Hydatellaceae possess nontrimerous reproductive organization and ascidiate carpels with unfused margins-Our developmental data show that pistils develop as completely ascidiate structures in both Trithuria and Hydatella. If
Hydatellaceae are correctly placed among early-divergent angiosperms, this phylogenetic context means that each pistil is most parsimoniously interpreted as a solitary ascidiate carpel. Other extant early-divergent angiosperms also possess ascidiate carpels (Endress and Igersheim, 2000a; Endress, 2001, 2005; Posluszny and Tomlinson, 2003; Schneider et al., 2003; Buzgo et al., 2004), which Doyle and Endress (2000) considered ancestral for angiosperms.

Admittedly, ascidiate carpel development closely resembles pistil development in pseudomonomerous grasses (Philipson, 1985). Interpretation of pseudomonomery represents an example of a morphological homology assessment at least partly dictated by presumed phylogenetic placement (Kelly and Stevenson, 2005). Thus, previous placement of Hydatellaceae among derived monocots (Poales) indicated pseudomonomery rather than monomery (e.g., Hieronymus, 1888); this interpretation was supported by the triquetrous fruit of Trithuria, with three vascular bundles, and the supposed presence of only three stigmatic hairs (which were erroneously interpreted as styles), suggesting a trimerous gynoecium. There are other instances in angiosperms for which pseudomonomery is postulated mainly by presumed phylogenetic context; for example, in Urtica interpretation of pseudomonomery is not supported by convincing developmental data (Payer, 1857). As Sattler (1975) observed, the fact that descriptive floral terminology is itself often interpretative represents a significant problem in homology assessments. Indeed, the debate surrounding the origin of the angiosperm flower (Bateman et al., 2006) is frequently hampered by typological interpretations.

Evidence from gynoecium vasculature is also problematic for interpretation of pseudomonomery. Some putative pseudomonomerous ovaries could be better interpreted as solitary ascidiate carpels (e.g., in Berberidaceae: Endress, 1995; Endress and Igersheim, 1999). The vascular supply of a putative pseudomonomerous gynoecium is often compared with the typical vasculature of a conduplicate carpel. The presence of three equally spaced carpel bundles in Hydatellaceae is a relatively unusual condition in angiosperms, though in some pistils of $T$. submersa two of the three bundles occur close together. Most conduplicate angiosperm carpels possess a dorsal bundle and one or two ventral bundles, but vascularization of ascidiate carpels is more diverse. For example, carpels of Brasenia and Cabomba (both CabombaceaeNymphaeales) usually possess three equally spaced carpel bundles at certain levels (Moseley et al., 1984; Endress, 2005), so a comparison with Hydatellaceae is plausible. Interestingly, our observations show that fruit dehiscence by three valves in Trithuria is due not to separation of the fruit faces, as suggested by Hooker (1858), but rather to hygroscopic curvature of the three equally spaced vascular bundles. This breaks the thin pericarp, though there are no specialized zones of dehiscence. This could be comparable to similarly irregular fruit dehiscence in some Nymphaeaceae (Kaden, 1951).

Our observations refute earlier suggestions of trimery in Hydatellaceae, especially Hooker's (1858) detailed description of Trithuria, which was illustrated with drawings that have subsequently been extensively reproduced. Hooker (1858) and others (e.g., Harden, 1993, reproduced by Saarela et al., 2007) illustrated three equal stigmatic hairs in T. submersa; other observers (e.g., Edgar, 1966) erroneously reported 2-3 equal bifid styles in Trithuria and 5-10 unequal, undivided styles in Hydatella. Our investigation shows no obvious morphological difference between Hydatella and Trithuria in this respect; 

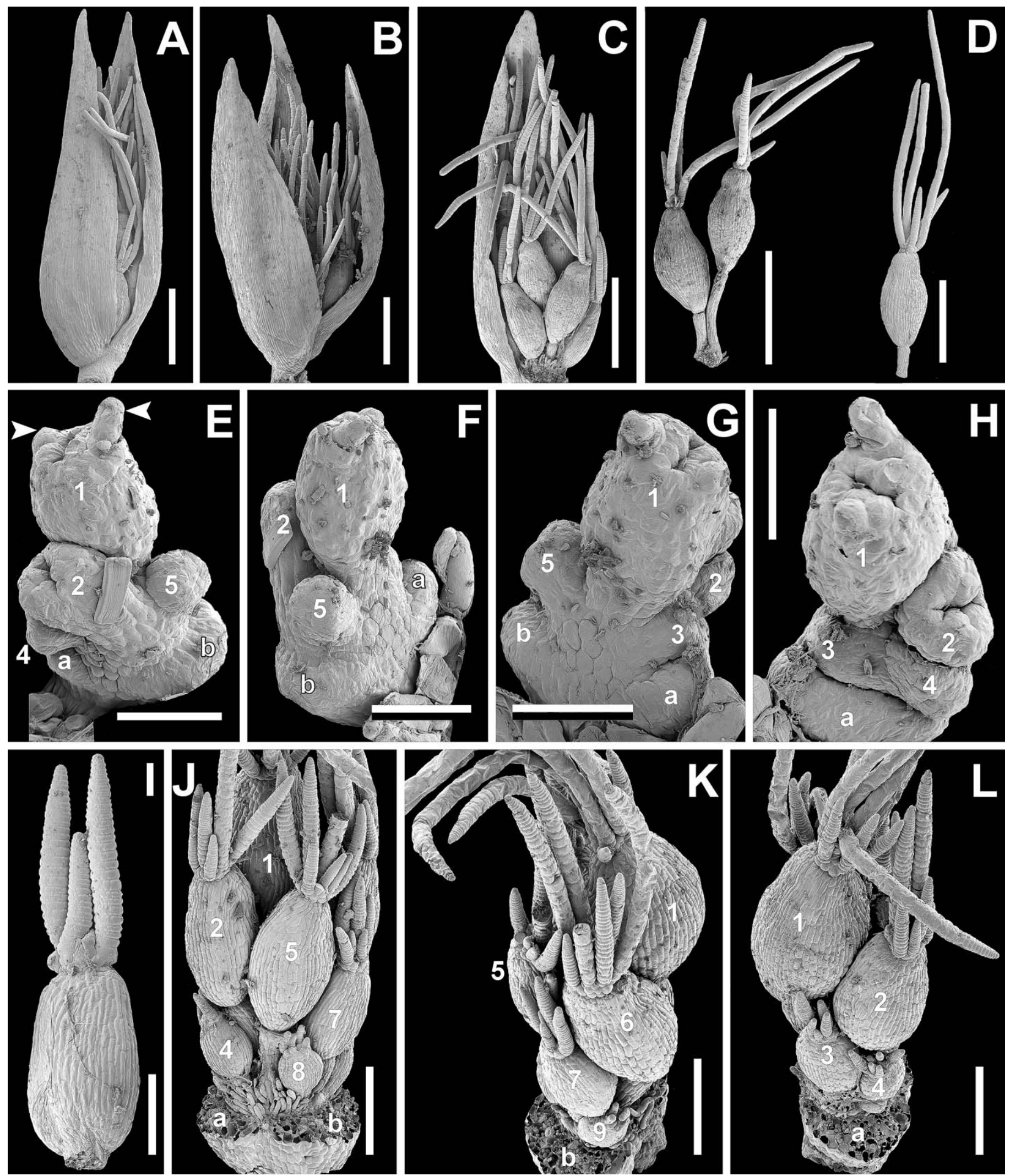

Fig. 10. SEM of Hydatella australis, preanthetic (A-D) and developing (E-L) female reproductive units (A-C, E-H, J-L) and pistils (D, I). (A) Lateral view of reproductive unit with two involucral bracts (most common type). (B) Lateral view of unit with three bracts (an unusual type). (C) Unit with one of two bracts removed. (D) Pistils. (E-H) Different lateral views of the same young reproductive unit (the sample is always rotated $90^{\circ}$ from the angle of the previous image). (I) A young pistil with three immature stigmatic papillae of unequal length. (J-L) Different lateral views of the same 


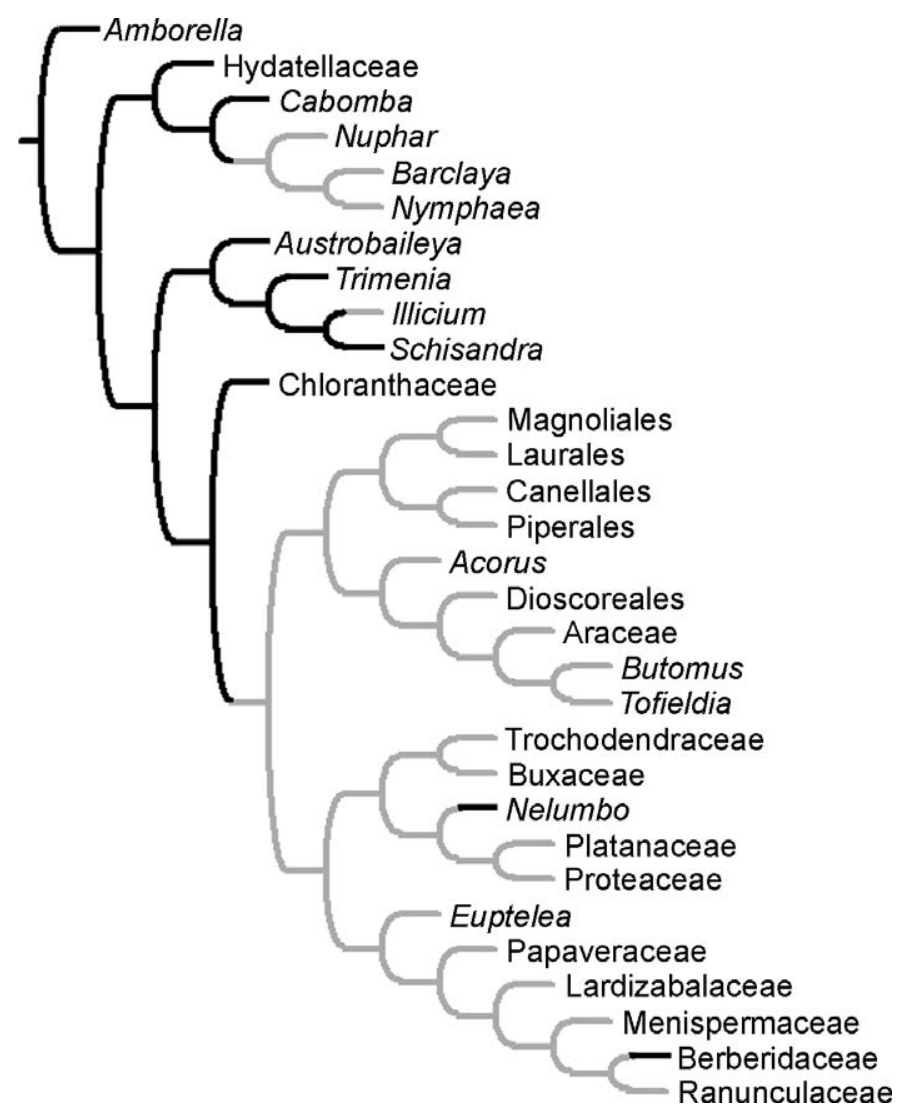

Fig. 11. Data for postgenital carpel closure (scored as absent vs. present based on data from Doyle and Endress, 2000; Endress and Igersheim, 2000a) optimized using WinClada (Nixon, 2002) onto the angiosperm tree from Saarela et al. (2007). Black lines indicate carpel margins unfused; gray lines indicate carpel margins at least partially postgenitally fused.

both possess a variable number of uniseriate stigmatic hairs that develop in succession and hence are of unequal length.

Carpels of many early-divergent angiosperms, albeit pronouncedly ascidiate, possess clear dorsiventral symmetry due to differential dorsal and ventral growth. By contrast, carpels of Hydatellaceae are more or less radially symmetric; bilateral symmetry is manifested mainly in the slightly elongate carpel opening, initiation of the first stigmatic hairs on one side, and position of ovule attachment. Ovules can be either dorsal or ventral in ascidiate carpels (Endress, 2005), making the position of ovule insertion difficult to determine in Hydatellaceae. If a single carpel represents an entire female flower in Hydatellaceae, this solitary position could be the cause of radial carpel symmetry. However, review of extensive data on flowers of basal angiosperms (e.g., Endress and Igersheim, 2000a) shows no obvious correlation between carpel number per flower and carpel symmetry. Indeed, the solitary ascidiate carpels of the phylogenetically isolated aquatic Ceratophyllum are pronouncedly bilateral (Shamrov, 1983; Endress, 1994; Iwamoto et al., 2003), but carpels of the trimerous gynoecium of Cabomba (a putative close relative of Hydatellaceae) are almost radially symmetric and similar to Hydatellaceae in early developmental stages (Endress, 2001; Schneider et al., 2003).

Endress and Igersheim (2000a) recognized four carpel types, which they termed angiospermy types $1-4$, according to the method of closure of individual carpels. Carpels are closed at anthesis in all early-divergent angiosperms, either exclusively by secretion (type 1, with unfused carpel margins) or by postgenital fusion of carpel margins, either incomplete (types 2,3 ) or complete (type 4). They concluded that angiospermy type 1 is the likely ancestral condition in angiosperms because it occurs in many of the earliest-divergent extant taxa such as Amborella, Cabomba, Austrobaileya, Kadsura, Trimenia, and Chloranthaceae. These taxa entirely lack postgenital fusion, despite close association of carpel margins from an early stage.

Endress and Igersheim (2000a) considered postgenital carpel closure to be an important key innovation of angiosperms, having been derived from carpel closure by secretion. However, carpels of Nymphaeaceae and Illicium are postgenitally closed at anthesis (Endress and Igersheim, 2000a), making evolution of this character homoplastic and its phylogenetic reconstruction sensitive to taxon sampling. Among other Nymphaeales, Cabombaceae lack postgenital carpel closure (Fig. 11). This feature is difficult to confidently determine in Hydatellaceae, but a short narrow canal remains at anthesis, with margins closely appressed, so we have scored postgenital carpel closure as absent in Hydatellaceae. In this case, the most parsimonious optimization supports Endress and Igersheim's (2000a) hypothesis that unfused carpel margins represent the ancestral angiosperm condition (Fig. 11).

In this context, we note that understanding carpel closure can be problematic in congenitally syncarpous taxa. If all carpels are congenitally united up to the stigma and the uppermost portion of the gynoecium is unilocular-symplicate, this leaves little space for postgenital fusion of individual carpel margins. For example, in the monocot Narthecium and many Papaveraceae (Ranunculales), the carpels are united up to the stigma, where an open canal is present (Endress and Igersheim, 1999; Remizowa et al., 2006). This condition can be described as angiospermy type 1 . In terms of function and development, it is close to the condition in solitary ascidiate carpels but doubtfully represents the same character state in a morphological cladistic analysis and might be better scored as "uncertain."

Interpretation of the reproductive units of Hydatellaceae-In Hydatellaceae, reproductive units consist of two or several perianth-like bracts that enclose several pistils and/or stamens. They differ considerably in structure from those of other earliest-divergent angiosperms such as Amborella and water lilies. A single unit in bisexual Hydatellaceae (e.g., Trithuria submersa) resembles an "inside-out" flower, in which stamens are surrounded by carpels. The sequence of carpel initiation is centrifugal in both bisexual and female

$\leftarrow$

developing reproductive unit (each view rotated $120^{\circ}$ from the previous image). a, b, involucral bracts or their removed bases; numerals, pistils; arrowheads, initiating stigmatic papillae. See Fig. 5 for diagrams of the same reproductive units with the same labeling. Scale bars $=500 \mu \mathrm{m}(\mathrm{A}-\mathrm{D}), 50 \mu \mathrm{m}$ $(\mathrm{E}-\mathrm{H}), 100 \mu \mathrm{m}(\mathrm{I})$, and $200 \mu \mathrm{m}(\mathrm{J}-\mathrm{L})$. 
reproductive units, in which carpel and stamen arrangement cannot be described as whorled, spiral, or even chaotic, but rather follows zigzag patterns (see also Hieronymus, 1888).

Thus, our data indicate that the reproductive units of Hydatellaceae do not represent typical flowers and could be interpreted in contrasting ways:

1. Each reproductive unit of Hydatellaceae could represent a "pre-floral state" - a step toward a true flower. A pre-floral reproductive condition was recently proposed for Archaefructus, a contentious fossil angiosperm from the Cretaceous (Sun et al., 2002). This interpretation has been challenged (Friis et al., 2003) but nevertheless establishes a significant hypothetical scenario, though we exclude a close relationship between Hydatellaceae and Archaefructus (see comparison with fossil taxa, below).

2. The unusual reproductive structures of Hydatellaceae, which show some inflorescence-like and some flower-like features, could have evolved through a loss of flower identity. For example, there is an intriguing similarity between the innerwhorl perianth members in Cabomba and the inner-whorl involucral bracts in Trithuria submersa: both are strongly retarded in development, a feature typical of petals in many eudicots (tricolpates) but highly unusual among earlydivergent angiosperms (Endress, 2001).

Although no close phylogenetic affinity is implied, reproductive structures of Hydatellaceae could be compared with the otherwise unique inside-out reproductive units of the monocot Lacandonia (Triuridaceae), in which the stamens are central and the flower-inflorescence boundary is ambiguous (VergaraSilva et al., 2003; Rudall, 2003; Rudall and Bateman, 2006). In Lacandonia, reproductive units develop centrifugally (Ambrose et al., 2006), as in Hydatellaceae. This could indicate a developmental constraint ensuring that the earliest-formed carpels are initiated close to the androecium, both in "normal" flowers and in "inside-out" reproductive units.

3. Finally, each reproductive unit could represent an inflorescence-a highly specialized aggregation of extremely reduced unisexual ("simple") flowers (Fig. 5D). This is the traditional, and perhaps currently the most plausible, interpretation, though it means that these structures are morphologically very different from those of other Nymphaeales. Simple tiny flowers are common in Early Cretaceous fossil floras (Friis et al., 2006), so it is questionable whether flowers of Hydatellaceae are reduced or primitively simple. They show intriguing similarity to the simple perianthless flowers of the early-divergent angiosperm Hedyosmum (Chloranthaceae), which is pollinated abiotically. In Hedyosmum, the male flower is a single stamen, and the female flower a single ascidiate carpel (of angiospermy type 1) bearing a solitary pendulous ovule, though in contrast to Hydatellaceae the ovule is orthotropous (Endress, 1987; Endress and Igersheim, 1997). Hedyosmum includes both extant and Early Cretaceous fossil species (Friis et al., 2006). Interestingly, Hedyosmum also has triquetrous fruits due to the presence of three apical ovary appendages that are usually interpreted as tepals. Thus, fruits and ovaries of Hedyosmum resemble those of Trithuria, though the stigmas are very different, and Trithuria lacks apical appendages.

If we accept reproductive units of Hydatellaceae as inflorescences, their structure is difficult to interpret because of the absence of flower-subtending bracts and the presence of a relatively simple vascular organization (D. D. Sokoloff and M. V. Remizowa, unpublished data). Hieronymus (1888) interpreted each reproductive unit in Trithuria submersa as a group of cymose monochasial partial inflorescences (cincinni), each cincinnus located in the axil of an involucral bract. The two male flowers represent the first flowers of two monochasia borne in the axils of the two outer-whorl involucral bracts. Although not stated explicitly by Hieronymus, this interpretation requires the presence of two further, entirely female cincinni borne in the axils of each of the two inner-whorl involucral bracts. We tentatively accept this interpretation based on our developmental data but note that one of the two stamens (i.e., a male flower) is strongly accelerated in development in $T$. submersa, indicating that it could occupy a terminal position within a partial inflorescence, though we consider this unlikely. However, in contrast to Hieronymus, we conclude that at least in some cases (see Fig. 5C, D) the partial inflorescence is initiated as a dichasium and then continues as two monochasia; this represents a double cincinnus sensu Weberling (1981).

In species with only two involucral bracts, it seems likely that a cincinnus occurs in the axil of each bract; thus, in contrast to $T$. submersa, there are two rather than four monochasia. As in T. submersa, the first flower to be initiated in the reproductive unit occupies an almost central position, and it is difficult to determine whether it represents a terminal flower or is the first flower of a cincinnus located in the axil of an involucral bract.

Hydatellaceae are well adapted to an aquatic habit-Many authors have discussed the frequent occurrence in aquatic plants of strong morphological reduction and high intraspecific variation, often associated with high plasticity (e.g., Arber, 1920; Bateman, 1996; Cook, 1999; Santamaría, 2002). Some features of Hydatellaceae, notably the aquatic habit, annual life form (in most species) allowing growth in a profoundly seasonal climate, and likely abiotic pollination, represent ecological adaptations and thus may not reflect ancestral character states, especially as the short generation time facilitates rapid evolution of adaptive traits. For example, the long stamen filaments of Hydatellaceae (a rare condition in early-divergent angiosperms - though present in wind-pollinated Brasenia - but common in eudicots and monocots) could be of adaptive significance, erecting the anther above the water level. Well-developed aerenchyma, which occurs in leaves of Hydatellaceae, is also clearly an adaptive feature. All species of Hydatellaceae are highly tolerant of submergence; for example, Hydatella inconspicua can grow up to $2 \mathrm{~m}$ in depth (Pledge, 1974). Stomata rarely occur in submerged species; our observations of a few stomata at leaf tips in $H$. australis (Fig. 2K) represent the first record of stomata in the genus, though anomocytic stomata occur on leaves of Trithuria. Apart from Nymphaeales, few other early-divergent angiosperms are aquatic, except for the phylogenetically isolated genus Ceratophyllum, which resembles Hydatellaceae in possessing ascidiate carpels bearing a solitary ovule (discussed previously) and abiotic underwater pollination (Endress, 1994; Iwamoto et al., 2003). However, the anthecology of Ceratophyllum is entirely different from that of Hydatellaceae (Shamrov, 1983), and they differ morphologically in many respects. 
Comparison with Amborella-In Amborella, the putative sister to all other angiosperms, the branching system is monoaxial (sensu Notov and Kusnetzova, 2004); i.e., each axis terminates in a flower (Posluszny and Tomlinson, 2003; Buzgo et al., 2004). Amborella resembles Hydatellaceae in possessing a cymose branching pattern. Furthermore, the carpel of Hydatellaceae resembles that of Amborella in possessing a single pendulous ovule, in contrast to more than one ovule in carpels of extant Nymphaeales, though a single ovule can occur as an exception in Cabombaceae (Wiersema, 1997), and fruits of some fossil Nymphaeaceae were probably single-seeded (Dorofeev, 1963). However, not surprisingly, given the very different biology of these plants, Amborella and Hydatellaceae differ in many respects. For example, there are significant differences in carpel and fruit vasculature: Amborella has a ventral and dorsal vascular bundles and a network of anastomosing secondary bundles (Endress and Igersheim, 1997, 2000b; Bobrov et al., 2005).

Comparison with extant and fossil Nymphaeales-Hydatellaceae contrast with the water-lily clade in several important respects, most notably in flower structure and arrangement. The apparently perianthless simple flowers of Hydatellaceae differ considerably from flowers of Nymphaeales, which possess a perianth enclosing multiple organs. Furthermore, our observations indicate a cymose branching pattern in Hydatellaceae, which is unusual for Nymphaeales, though Nuphar and Nymphaea have a peculiar branching pattern with flowers replacing leaves in the ontogenetic spiral (Weidlich, 1976a, b; Schneider et al., 2003; Grob et al., 2006, and other references cited therein). One could speculate that the flowersubtending bract is merely suppressed in Nymphaea, on the basis of observations of bract-like organs at the base of pedicel in Nuphar (reviewed by Schneider et al., 2003), but occasional observations of more than one such bract in Nuphar makes such a hypothesis problematic. Admittedly, the main axis never forms a terminal flower either in Hydatellaceae or in Nymphaea, Nuphar, or (probably) other Nymphaeaceae (Weidlich, 1976a, b, 1980). Branching systems of complete plants require careful investigation in Hydatellaceae to determine whether the apex of their peduncles is comparable with the inflorescence apex of Amborella and the rhizome apex of Nymphaeaceae. Alternative interpretations are possible here.

Conversely, some morphological similarities support a close relationship between Hydatellaceae and Nymphaeales. For example, the short multicellular, apparently secretory hairs that occur between carpels and stamens of Hydatellaceae (Figs. 2F, $8 \mathrm{~B}, 9 \mathrm{E})$ resemble similar hairs that occur in flowers of some Nymphaeales (e.g., Brasenia, in which these hairs also develop before stigmatic papillae: Endress, 2005). However, short glandular hairs are also common in Poales and other commelinids, including Commelinaceae, Eriocaulaceae, and Poaceae (e.g., Tomlinson, 1969).

Other similarities between Hydatellaceae and Nymphaeales include aspects of embryology and seed morphology, especially the four-celled female megagametophyte reported by Hamann (1962, 1975, 1976, 1998). Megagametophyte and ovule/seed characters will be the subject of further research in light of the hypothesis that an ancestral four-nucleate/fourcelled condition, which occurs in several early-divergent angiosperms (Battaglia, 1986; Winter and Shamrov, 1991a, b; Batygina and Vasilyeva, 1994, 1996; Williams and Friedman, 2002, 2004; Friedman et al., 2003), gave rise to the more common eight-nucleate/seven-celled condition in angiosperms (Friedman and Williams, 2003, 2004; Williams and Friedman, 2004).

In contrast to other extant early-divergent angiosperms, seeds of Nymphaeaceae and especially Cabombaceae resemble those of Hydatellaceae in the presence of starchy perisperm, relatively sparse endosperm, and in details of seed coat anatomy (reviewed by Collinson, 1980; Kolesova and Batygina, 1988; Melikian and Nemirovich-Danchenko, 1988; Cevallos-Ferriz and Stockey, 1989), especially thickened exotesta cells and a cap (operculum) with thickened tegmen cells at the micropylar end. However, at least some of these characters may be adaptive; operculate seeds also occur in several monocots, such as the early-divergent monocot Pistia, though this differs in seed coat structure (Vyshenskaya, 1985; Buzgo, 1994), and the commelinid family Restionaceae (Poales), including putative fossil species (Dettmann and Clifford, 2000). A copious starchy perisperm is a feature of Nymphaeaceae and Cabombaceae (e.g., Batygina et al., 1980; Floyd and Friedman, 2000) but also occurs in several monocots, including some Poales (e.g., Ecdeiocolea: Rudall, 1990, 1997) and Pistia (Vyshenskaya, 1985; Buzgo, 1994). In both Hydatellaceae and Nymphaeales, the endosperm does not develop beyond the early stages, in contrast to Poales, in which the endosperm is well developed.

The fossil seed record of Cabombaceae and Nymphaeaceae is extensive (Dorofeev, 1963, 1974, 1984; Collinson, 1980; Cevallos-Ferriz and Stockey, 1989; Krassilov et al., 2005; Friis et al., 2006; Taylor et al., 2006), partly due to their preference for aquatic habitats with good preservation potential (MartínClosas, 2003). Seeds of both extant and extinct Cabombaceae, and many (though not all) Nymphaeaceae, differ from those of Hydatellaceae in that their exotesta cells possess undulating anticlinal walls, a feature that has not been observed in Hydatellaceae (Fig. 7E, F). However, the significance of this feature (which occurs in the earliest-known Cretaceous fossil seeds of Nymphaeales) is equivocal, because it also occurs in Illiciaceae (Friis et al., 2006) and other more distantly related families. Hydatellaceae resemble Cabombaceae in possessing clear longitudinal rows of exotestal cells (Collinson, 1980; Dorofeev, 1974). Among the two extant genera of Cabombaceae, the seed coat of Hydatellaceae more closely resembles that of Cabomba (which lacks a clear fossil record) than Brasenia. Brasenia possesses a columnar sclerotesta with very thick outer periclinal and anticlinal walls (Collinson, 1980; Kolesova and Batygina, 1988); a similar structure has been described in its fossil relatives (Collinson, 1980; Dorofeev, 1984). By contrast, the seed coat of Cabomba is relatively thin, with less thickened exotestal walls, as in Hydatellaceae (cf. Hamann et al., 1979; Collinson, 1980). Fassett (1953, cited by Collinson, 1980) commented that the tubercles formed by the exotesta cells of Cabomba appear to be absent from dry seeds but may be expanded by wetting, rather as described here for exotestal cells of Trithuria submersa.

Comparison with fossil taxa other than Nymphaeales-As far as we know, no fossils have been described that closely match material of Hydatellaceae. Indeed, the minute size, especially of the pollen, means that they would probably be overlooked during most processes of fossil preparation. Saarela et al. (2007) suggested the possibility of a close relationship between Hydatellaceae and the early Cretaceous fossil Archaefructus because both are aquatics with perianthless 
flowers and probably share abiotic pollination by wind or water. However, reproductive architecture shows little in common between the highly condensed reproductive units of Hydatellaceae and the attenuated units of Archaefructus, in which male structures occur below female structures. Furthermore, numerous other features distinguish Archaefructus from Hydatellaceae, including dissected leaves, sessile stamens, and multiovulate carpels.

Perhaps a more compelling (though probably equally homoplastic) ecophysiological parallel with Hydatellaceae can be drawn from some lakebed deposits of Siberia and Kazakhstan from the late Jurassic and early Cretaceous (i.e., the most commonly postulated time of early angiosperm diversification). These deposits contain abundant, small, achene-like diaspores, each bearing a cluster of hairs or bristles (Krassilov and Bugdaeva, 1982; Krassilov, 1997). For example, the fossil Baisia consists of dispersed cupulate ovules that are apical on a short persistent receptacle that bears numerous long bristles, possibly adapted to dispersal by adhering to furred animals (epizoochory) (Krassilov, 1997). The dispersed fruits of Hydatella are superficially similar, though the long, persistent receptacular bristles in Baisia are unlikely homologs with the multicellular stigmatic hairs of Hydatellaceae. Baisia itself is probably not an angiosperm (e.g., Crane, 1996) and not a close relative of Hydatellaceae, but some other, less well-studied fossil diaspores of this ecological type merit detailed comparison, including diaspores of Cretaceous fossil aquatics from Australia.

Baisia and other early Cretaceous compression fossils have been variously compared with Bennettitales, angiosperms, and Gnetales (Krassilov and Bugdaeva, 1982; Crane, 1996; Krassilov, 1997). The comparison with Gnetales, though presumably also superficial, is interesting because Gnetales are characterized by decussate bracts enclosing ovules. These structures are not morphologically homologous to reproductive units of Hydatellaceae, but poorly preserved compression fossils of reproductive units similar to Hydatellaceae could be mistaken for reproductive structures of Gnetales, especially when stomata are not preserved.

Conclusions - The highly unusual morphology of Hydatellaceae, exemplified by their remarkable stigmatic hairs and floral morphology, at least partly explains their problematic phylogenetic placement. This relative isolation was eloquently expressed by Hamann (1976) and Dahlgren et al. (1985) (in quotes at the beginning of this paper). Placement in Nymphaeales was understandably not considered earlier because of the extreme divergence between reproductive units of Hydatellaceae and Nymphaeales. Hydatellaceae are monocot-like in several respects; for example, their annual rosette growth form with linear leaves is unique among earlydivergent angiosperms. Interpretation of some characters is dependent on phylogenetic placement; most notably the nature of the pistil-whether a solitary ascidiate carpel, as in earlydivergent angiosperms, or a pseudomonomerous gynoecium, as in Poaceae. Furthermore, Nymphaeales and monocots share many features. Saarela et al. (2007) listed several "unequivocal synapomorphies" supporting a close relationship between Hydatellaceae and Nymphaeales; however, many of these features are also common in monocots, including lack of vascular cambium, anomocytic stomata, boat-shaped pollen, inner integument with two cell layers, perisperm, and hypogeal germination. Ecophysiology is an important factor linking
Hydatellaceae with both Nymphaeales and some monocots. Presumably, at least some of the numerous interesting parallels that exist between Nymphaeales and monocots represent convergences due to the shared aquatic habit. Perhaps ironically, potentially the most persuasive set of morphological synapomorphies between Hydatellaceae and Nymphaeales lies in the very characters that prompted Hamann (1976) to finally segregate Hydatellaceae from Centrolepidaceae, especially embryology and seed morphology.

\section{LITERATURE CITED}

Ambrose, B. A., S. Espinosa-Matías, S. Vázquez-Santana, F. VergaraSilva, E. Martínez, J. Márquez-Guzmán, and E. R. Alvarez-Buylla. 2006. Comparative floral developmental series of the Mexican triurids support a euanthial interpretation for the unusual floral structures of Lacandonia schismatica (Lacandoniaceae). American Journal of Botany 93: 15-35.

Arber, A. 1920. Water plants: a study of aquatic angiosperms. Cambridge University Press, Cambridge, UK.

Bateman, R. M. 1996. Nonfloral homoplasy and evolutionary scenarios in living and fossil land plants. In M. J. Sanderson and L. Hufford [eds.], Homoplasy: the recurrence of similarity in evolution, 91-130. Academic Press, London, UK.

Bateman, R. M., J. Hilton, and P. J. Rudall. 2006. Morphological and molecular phylogenetic context of the angiosperms: contrasting the "top-down" and "bottom-up" approaches to inferring the likely characteristics of the first flowers. Journal of Experimental Botany 57: 3471-3503.

Battaglia, E. 1986. Embryological questions: 7. Do new types of embryo sac occur in Schisandra? Annals of Botany 44: 69-92.

Batygina, T. B., T. I. Kravtsova, and I. I. Shamrov. 1980. The comparative embryology of some representatives of the orders Nymphaeales and Nelumbonales. Botanichesky Zhurnal 65: 10711086.

Batygina, T. B., And V. E. Vasilyeva. 1994. Oenothera-type [of embryo sac development]. In T. B. Batygina [ed.], Embryology of flowering plants: terminology and concepts, vol. 1, Generative organs of flower, 218-222. World and Family, St. Petersburg, Russia.

Batygina, T. B., And V. E. Vasilyeva. 1996. The revision of Oenotheratype of embryo sac development in angiosperms. In K. G. Mukerji [ed.], Advances in botany, 1-20. A. P. H. Publishing, New Delhi, India.

BeHnke, H. D. 1976. The distribution of characters within an angiosperm system. Botaniska Notiser 129: 287-295.

Behnke, H. D. 2000. Forms and sizes of sieve-element plastids and evolution of the monocots. In K. L. Wilson and D. A. Morrison [eds.], Monocots: systematics and evolution, 163-188. CSIRO, Melbourne, Australia.

Bobrov, A. V. F. C., P. K. Endress, A. P. Melikian, M. S. Romanov, A. N. Sorokin, and A. Palmarola Bejerano. 2005. Fruit structure of Amborella trichopoda (Amborellaceae). Botanical Journal of the Linnean Society 148: 265-274.

Bortenschlager, S., G. Erdtman, and J. Praglowski. 1966. Pollenmorphologische Notizen über einige Blütenpflanzen incertae sedis. Botaniska Notiser 119: 160-168.

Buzgo, M. 1994. Inflorescence development of Pistia stratiotes (Araceae). Botanische Jahrbücher 115: 557-570.

BuzGo, M., AND P. K. Endress. 2000. Floral structure and development of Acoraceae and its systematic relationships with basal angiosperms. International Journal of Plant Sciences 161: 23-41.

Buzgo, M., P. S. Soltis, And D. S. Soltis. 2004. Floral developmental morphology of Amborella trichopoda (Amborellaceae). International Journal of Plant Sciences 165: 925-947.

Cevallos-Ferriz, S. R. S., And R. A. Stockey. 1989. Permineralized fruits and seeds from the Princeton Chert (Middle Eocene) of British Columbia: Nymphaeaceae. Botanical Gazette 150: 207-217.

Cheeseman, T. F. 1907. Notice on the occurrence of Hydatella, a new genus to the New Zealand flora. Transactions of the New Zealand Institute 39: 433-434. 
Collinson, M. E. 1980. Recent and tertiary seeds of the Nymphaeaceae sensu lato with a revision of Brasenia ovula (Brong.) Reid and Chandler. Annals of Botany 46: 603-632.

Cook, C. D. K. 1999. The number and kinds of embryo-bearing plants which have become aquatic: a survey. Perspectives in Plant Ecology, Evolution and Systematics 2: 79-102.

Cooke, D. A. 1981. New species of Schoenus (Cyperaceae) and Trithuria (Hydatellaceae). Muelleria 4: 299-303.

Cooke, D. A. 1983. The seedling of Trithuria (Hydatellaceae). Victorian Naturalist 100: 68-69.

Cooke, D. A. 1987. Hydatellaceae. In A. S. George [ed.], Flora of Australia, vol. 45, 1-5. Australian Government Publishing Service, Canberra, Australia.

Crane, P. R. 1996. The fossil history of Gnetales. International Journal of Plant Sciences 157 (Supplement): S50-S57.

Cutler, D. F. 1969. Anatomy of the Monocotyledons. IV. Juncales. Oxford University Press, Oxford, UK.

Dahlgren, R. M. T., H. T. Clifford, and P. F. Yeo. 1985. The families of the monocotyledons. Springer, Berlin, Germany.

DetTmann, M. E., And H. T. ClifFord. 2000. Monocotyledon fruits and seeds, and an associated palynoflora from Eocene-Oligocene sediments of coastal central Queensland, Australia. Review of Palaeobotany and Palynology 110: 141-173.

Diels, L., AND E. PRITZEL. 1904. Fragmenta phytographiae Australiae occidentalis. Botanische Jahrbücher 35: 55-662.

DorofeEv, P. I. 1963. Tertiary floras of western Siberia. Komarov Botanical Institute of Academy of Sciences of USSR, Leningrad, USSR.

DorofeEv, P. I. 1974. Nymphaeales. In A. Takhtajan [ed.], Magnoliophyta fossilia URSS, vol. 1, Magnoliaceae-Eucommiaceae, 52-88. Nauka, Leningrad, USSR.

DorofeEv, P. I. 1984. The taxonomy and history of the genus Brasenia (Cabombaceae). Botanicheskij Zurnal 69: 137-148.

Doyle, J. A., AND P. K. EndREss. 2000. Morphological phylogenetic analysis of basal angiosperms: comparison and combination with molecular data. International Journal of Plant Sciences 161: S121S153.

EDGAR, E. 1966. The male flowers of Hydatella inconspicua (Cheesem.) Cheesem. (Centrolepidaceae). New Zealand Journal of Botany 4: $153-158$.

EndRESS, P. K. 1987. The Chloranthaceae: reproductive structures and phylogenetic position. Botanische Jahrbücher 109: 153-226.

ENDRESS, P. K. 1994. Evolutionary aspects of the floral structure in Ceratophyllum. Plant Systematics and Evolution 8 (Supplement): $175-183$.

ENDRESS, P. K. 1995. Floral structure and evolution in Ranunculanae. Plant Systematics and Evolution 9 (Supplement): 47-61.

EndRESS, P. K. 2001. The flowers in basal extant angiosperms and inferences on ancestral flowers. International Journal of Plant Sciences 162: 1111-1140.

ENDRESS, P. K. 2005. Carpels in Brasenia (Cabombaceae) are completely ascidiate despite a long stigmatic crest. Annals of Botany 96: 209215.

EndRess, P. K., AND A. IgERSheim. 1997. Gynoecium diversity and systematics of the Laurales. Botanical Journal of the Linnean Society 125: 93-168.

Endress, P. K., AND A. Igersheim. 1999. Gynoecium diversity and systematics of the basal eudicots. Botanical Journal of the Linnean Society 130: 305-393.

Endress, P. K., AND A. Igersheim. 2000a. Gynoecium structure and evolution in basal angiosperms. International Journal of Plant Sciences 161: S211-S223.

ENDRESS, P. K., AND A. IGERSHeIm. 2000b. The reproductive structures of the basal angiosperm Amborella trichopoda (Amborellaceae). International Journal of Plant Sciences 161: S237-S248.

FassetT, N. C. 1953. A monograph on the genus Cabomba. Castanea 18: $116-128$.

Field, T. S., AND N. C. ARENs. 2005. Form, function and environments of the early angiosperms: merging extant phylogeny and ecophysiology with fossils. New Phytologist 166: 383-408.

Floyd, S. K., and W. E. Friedman. 2000. Evolution of endosperm developmental patterns among basal flowering plants. International Journal of Plant Sciences 161 (Supplement): S57-S81.

Friedman, W. E., W. N. Gallup, and J. H. Williams. 2003. Female gametophyte development in Kadsura: implications for Schisandraceae, Austrobaileyales, and the early evolution of flowering plants. International Journal of Plant Sciences 164 (Supplement): S293S305.

Friedman, W. E., AND J. H. Williams. 2003. Modularity of the angiosperm female gametophyte and its bearing on the early evolution of endosperm in flowering plants. Evolution 57: 216-230.

Friedman, W. E., AND J. H. Williams. 2004. Developmental evolution of the sexual process in ancient flowering plant lineages. Plant Cell 16: S119-S132.

Fris, E. M., J. A. Doyle, P. K. Endress, and Q. Leng. 2003. Archaefructus - angiosperm precursor or specialized early angiosperm? Trends in Plant Science 8: 369-373.

Fris, E. M., K. R. Pedersen, and P. R. Crane. 2006. Cretaceous angiosperm flowers: innovation and evolution in plant reproduction. Paleogeography, Paleoclimatology, Paleoecology 232: 251-293.

Furness, C. A., AND P. J. Rudall. 2004. Pollen aperture evolution-a crucial factor for eudicot success? Trends in Plant Science 9: 13601385.

Grayum, M. H. 1987. A summary of evidence and arguments supporting the removal of Acorus from the Araceae. Taxon 36: 723-729.

Grob, V., P. Moline, E. Pfeifer, A. R. Novelo, and R. Rutishauser. 2006. Developmental morphology of branching flowers in Nymphaea prolifera. Journal of Plant Research 119: 561-570.

Hamann, U. 1962. Beitrag zur Embryologie der Centrolepidaceae mit Bemerkungen uber den Bau der Bluten und Blutenstande und die systematische Stellung der Familie. Berichte der Deutschen Botanischen Gesellschaft 75: 153-171.

Hamann, U. 1975. Neue Untersuchungen zur Embryologie und Systematik der Centrolepidaceae. Botanische Jahrbücher 96: 154-191.

Hamann, U. 1976. Hydatellaceae-a new family of Monocotyledoneae. New Zealand Journal of Botany 14: 193-196.

Hamann, U. 1998. Hydatellaceae. In K. Kubitzki [ed.], Families and genera of vascular plants, vol. IV, Flowering plants-Monocotyledons-Alismatanae and Commelinanae, 231-234. Springer, Berlin, Germany.

Hamann, U., K. Kaplan, and T. Rübsamen. 1979. Über die Samenschalenstruktur der Hydatellaceae (Monocotyledoneae) und die systematische Stellung von Hydatella filamentosa. Botanische Jahrbücher 100: 555-563.

Hieronymus, G. 1873. Beiträge zur Kentniss der Centrolepidaceen. Abhandlungen der Naturforschende Gesellschaft zu Halle 12: 115222.

Hieronymus, G. 1888. Centrolepidaceae. In A. Engler and K. Prantl [eds.] Die Natürlichen Pflanzenfamilien, vol. II, part 4, 11-16. W. Engelmann, Leipzig, Germany.

Hooker, J. D. 1858. Flora of Tasmania, vol. 2. L. Reeve, London, UK.

Iwamoto, A., A. Shimizu, And H. Онва. 2003. Floral development and phyllotaxic variation in Ceratophyllum demersum (Ceratopyllaceae). American Journal of Botany 90: 1124-1130.

KadEN, N. N. 1951. Fruits and seeds of Middle Russian Nymphaeaceae and Berberidaceae. Bulletin of Moscow Society of Naturalists, Biological Series 56: 81-90.

Kelly, L. M., And D. W. Stevenson. 2005. Floral morphological character coding and the use of trees. In Abstracts of the XVII International Botanical Congress, Vienna, Austria, 12.3.1.

Kolesova, G. E., and T. B. Batygina. 1988. Cabombaceae. In A. Takhtajan [ed.], Anatomia seminum comparativa 2, 136-140. Nauka, Leningrad, USSR.

Krassilov, V. A. 1997. Angiosperm origins: morphological and ecological aspects. Pensoft, Sofia, Bulgaria.

Krassilov, V. A., and E. V. Bugdaeva. 1982. Achene-like fossils from the Lower Cretaceous of the lake Baikal area. Review of Palaeobotany and Palynology 36: 279-295.

Krassilov, V. A., Z. Lewy, E. Nevo, and N. Silantieva. 2005. Late Cretaceous (Turonian) flora of Southern Negev, Israel. Pensoft, Moscow, Russia. 
Linder, H. P. 1987. The evolutionary history of the Poales/Restionales-a hypothesis. Kew Bulletin 42: 297-318.

Martín-Closas, C. 2003. The fossil record and evolution of freshwater plants: a review. Geologica Acta 1: 315-338.

Melikian, A. P., and E. N. Nemirovich-DanchenKo. 1988. Nymphaeaceae. In A. Takhtajan [ed.], Anatomia seminum comparativa 2, 140-147. Nauka, Leningrad, USSR.

Moseley, M. F., I. J. Mehta, P. S. Williamson, and H. Kosakai. 1984. Morphological studies of the Nymphaeaceae (sensu lato). XIII. Contributions to the vegetative and floral structure of Cabomba. American Journal of Botany 7: 902-924.

Nixon, K. C. 2002. WinClada, version 1.00.08. Ithaca, New York, USA. Computer program published and distributed by the author. Website http://www.cladistics.com.

Notov, A. A., And T. V. Kusnetzova. 2004. Architectural units, axiality and their taxonomic implications in Alchemillinae. Wulfenia 11: 85130.

PAYER, J. B. 1857. Traité d'organogénie comparée de la fleur. Librarie de Victor Masson, Paris, France.

Philipson, W. R. 1985. Is the grass gynoecium monocarpellary? American Journal of Botany 72: 1954-1961.

Pledge, D. H. 1974. Some observations on Hydatella inconspicua (Cheesem.) Cheesem. (Centrolepidaceae). New Zealand Journal of Botany 12: 559-561.

Posluszny, U., And P. B. Tomlinson. 2003. Aspects of inflorescence and floral development in the putative basal angiosperm Amborella trichopoda (Amborellaceae). Canadian Journal of Botany 81: 28-39.

Qiu, Y. L., L. Li, T. A. Hendry, R. Li, D. W. TaYlor, M. J. Issa, A. J. Ronen, M. L. VeKaria, AND A. M. White. 2006. Reconstructing the basal angiosperm phylogeny: evaluating information content of mitochondrial genes. Taxon 55: 837-856.

Remizowa, M., D. Sokoloff, and P. J. Rudall. 2006. Evolution of the monocot gynoecium: evidence from comparative morphology and development in Tofieldia, Japonolirion, Petrosavia and Narthecium. Plant Systematics and Evolution 258: 183-209.

Rudall, P. J. 1990. Development of the ovule and megagametophyte in Ecdeiocolea monostachya. Australian Systematic Botany 3: 265-274.

Rudall, P. J. 1997. The nucellus and chalaza in monocotyledons: structure and systematics. Botanical Review 63: 140-184.

Rudall, P. J. 2000. Coding micromorphological characters in monocotyledon systematics. In T. Pennington and R. Scotland [eds.], Homology and systematics, 114-123. Taylor and Francis, New York, New York, USA.

RudALl, P. J. 2003. Monocot pseudanthia revisited: floral anatomy and systematics of the mycoheterotrophic family Triuridaceae. International Journal of Plant Sciences 164 (Supplement 5): S307-S320.

Rudall, P. J., AND M. Buzgo. 2002. The evolutionary history of the monocot leaf. In Q. C. B. Cronk, R. M. Bateman, and J. Hawkins [eds.], Developmental genetics and plant evolution, 432-458. Taylor and Francis, London, UK.

Rudall, P. J., AND C. A. Furness. 1997. Systematics of Acorus: ovule and anther. International Journal of Plant Sciences 158: 640-651.

Rudall, P. J., AND R. M. BATEMAN. 2006. Morphological phylogenetic analysis of Pandanales: testing contrasting hypotheses of floral evolution. Systematic Botany 31: 223-238.

Saarela, J. M., H. S. Rai, J. A. Doyle, P. K. Endress, S. Mathews, A. D. Marchant, B. G. Briggs, and S. W. Graham. 2007. Hydatellaceae identified as a new branch near the base of the angiosperm phylogenetic tree. Nature 446: 312-315.

SANTAMARÍA, L. 2002. Why are most aquatic plants widely distributed? Dispersal, clonal growth and small-scale heterogeneity in a stressful environment. Acta Oecologica 23: 137-154.

SATtLER, R. 1975. Organogenesis of flowers-a photographic text-atlas. University of Toronto Press, Toronto, Canada.

Schneider, E. L., S. C. Tucker, and P. S. Williamson. 2003. Floral development in the Nymphaeales. International Journal of Plant Sciences 164: S279-S292.

Shamrov, I. I. 1983. Anthecological investigation of three species of the genus Ceratophyllum (Ceratophyllaceae). Botanichesky Zhurnal 68: 1357-1366.

Sokoloff, D. D., M. V. Remizowa, T. D. Macfarlane, and P. J. Rudall. In press. Classification of the early-divergent angiosperm family Hydatellaceae: one genus instead of two, four new species, and sexual dimorphism in dioecious taxa. Taxon.

Soltis, D. E., P. S. Soltis, M. W. Chase, M. E. Mort, D. C. Albach, M. Zanis, V. Savolainen, W. H. Hahn, S. B. Нoot, M. F. Fay, M. Axtell, S. M. Swensen, L. M. Prince, W. J. Kress, K. C. Nixon, and J. S. FARRIS. 2000. Angiosperm phylogeny inferred from 18S rDNA, $r b c L$ and atpB sequences. Botanical Journal of the Linnean Society 133: 381-461.

Stevenson, D. W., AND H. Loconte. 1995. Cladistic analysis of monocot families. In P. J. Rudall, P. J. Cribb, D. F. Cutler, and C. J. Humphries [eds.], Monocotyledons: systematics and evolution, 543-578. Royal Botanic Gardens, Kew, UK.

Sun, G., O. Ji, D. L. Dilcher, S. Zheng, K. C. Nixon, and X. Wang. 2002. Archaefructaceae, a new basal angiosperm family. Science 296: 899904.

Takhtajan, A. L. 1966. System and phylogeny of flowering plants. Nauka, Leningrad, USSR.

Taylor, W., M. L. DeVore, and K. B. Pigg. 2006. Susiea newsalemae gen. et sp. nov. (Nymphaeaceae): Euryale-like seeds from the Late Paleocene Almont Flora, North Dakota, USA. International Journal of Plant Sciences 167: 1271-1278.

Tillich, H. J. 1990. The seedlings of Nymphaeaceae-monocotylar or dicotylar? Flora 184: 169-176.

Tomlinson, P. B. 1969. Anatomy of the monocotyledons. III. Commelinales-Zingiberales. Clarendon Press, Oxford, UK.

Vergara-Silva, F., S. Espinosa-Matiás, B. A. Ambrose, A. VázquezSantana, J. Matǐnez-Mena, E. Márquez-Guzmán, E. Meyerowitz, AND E. R. Alvarez-BuYLla. 2003. Inside-out flowers characteristic of Lacandonia schismatica (Lacandoniaceae: Triuridales) evolved at least before the divergence from its sister taxon, Triuris brevistylis. International Journal of Plant Sciences 164: 345-357.

Vyshenskaya, T. D. 1985. Hydatellaceae, Araceae. In A. Takhtajan [ed.], Anatomia seminum comparativa 2, 190-192, 264-275. Nauka, Leningrad, USSR.

WeiduICH, W. H. 1976a. The organization of the vascular system in the stems of the Nymphaeaceae. I. Nymphaea subgenera Castalia and Hydrocallis. American Journal of Botany 63: 499-509.

Weiduich, W. H. 1976b. The organization of the vascular system in the stems of the Nymphaeaceae. II. Nymphaea subgenera Anecphya, Lotos, and Brachyceras. American Journal of Botany 63: 1365-1379.

WeIDLICH, W. H. 1980. The organization of the vascular system in the stems of the Nymphaeaceae. III. Victoria and Euryale. American Journal of Botany 67: 790-803.

Wettstein, R. 1924. Handbuch der Systematischen Botanik, vol. 3. Franz Deuticke, Leipzig, Germany.

Wiersema, J. H. 1997. Cabombaceae. In Flora of North America Editorial Committee [eds.], Flora of North America 3: 78-80. Oxford University Press, Oxford, UK.

Williams, J. H., and W. E. Friedman. 2002. Identification of diploid endosperm in an early angiosperm lineage. Nature 415: 522-526.

Williams, J. H., AND W. E. Friedman. 2004. The four-celled female gametophyte of Illicium (Illiciaceae; Austrobaileyales): implications for understanding the origin and early evolution of monocots, eumagnoliids, and eudicots. American Journal of Botany 91: 332351.

Winter, A. N., AND I. I. Shamrov. 1991a. The development of the ovule and embryo sac in Nuphar lutea (Nymphaeaceae). Botanichesky Zhurnal 76: 378-390.

WinTER, A. N., AND I. I. Shamrov. 1991b. Megasporogenesis and embryo sac development in representatives of the genera Nymphaea and Victoria (Nymphaeaceae). Botanichesky Zhurnal 76: 1716-1728.

YADAV, S. R., AND M. K. Janarthanam. 1994. Hydatellaceae: a new family to the Indian flora with a new species. Rheedea 4: 17-20. 